\section{Production and persistence of annual pasture legumes at five saline sites in southern}

\section{Australia}

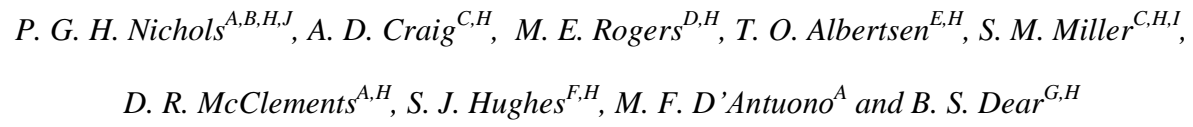

${ }^{A}$ Department of Agriculture and Food Western Australia, Locked Bag 4, Bentley Delivery Centre WA 6983, Australia.

${ }^{\mathrm{B}}$ School of Plant Biology, Faculty of Natural and Agricultural Sciences, The University of Western Australia, Crawley WA 6009, Australia.

${ }^{\mathrm{C}}$ South Australian Research and Development Institute, Struan Research Centre, PO Box 618, Naracoorte, SA 5271, Australia.

${ }^{D}$ Primary Industries Research Victoria, Department of Primary Industries Victoria, Tatura, Vic 3616, Australia.

${ }^{E}$ Department of Agriculture and Food Western Australia, Great Southern Agricultural Research Institute, Katanning, WA 6317, Australia.

${ }^{\mathrm{F}}$ South Australian Research and Development Institute, Plant Research Centre, Waite Campus, Adelaide, SA 5001, Australia.

${ }^{\mathrm{G}} \mathrm{EH}$ Graham Centre for Agricultural Innovation (Alliance between New South Wales Department of Primary Industries and Charles Sturt University), Pine Gully Road, Wagga Wagga, NSW 2650, Australia.

${ }^{\mathrm{H}}$ Cooperative Research Centre for Plant-based Management of Dryland Salinity, The University of Western Australia, 35 Stirling Highway, Crawley, WA 6009, Australia. ${ }^{\text {I}}$ Current address: South East Natural Resources Management Board, Mount Gambier, SA 5290, Australia.

${ }^{\mathrm{J} C}$ Corresponding author: email: pnichols@agric.wa.gov.au

Short title: Annual legumes on saline land 
1 Abstract. Herbage production and persistence of 42 annual pasture legumes from 33 species were measured at 5 sites across southern Australia. Medicago polymorpha L. was highly productive on soils, particularly those not prone to waterlogging, with $0-10 \mathrm{~cm} \mathrm{EC}_{\mathrm{e}}$

4 levels in summer of up to $36 \mathrm{dS} / \mathrm{m}$, while M. truncatula Gaertn. was productive on levels of at least $11 \mathrm{dS} / \mathrm{m}$. Trifolium michelianum Savi and T. resupinatum L. were highly productive on soils subject to waterlogging, but only where $0-10 \mathrm{~cm}$ summer $\mathrm{EC}_{\mathrm{e}}$ levels were less than $8 \mathrm{dS} / \mathrm{m}$. No commercial species were adapted to highly saline $(0-10 \mathrm{~cm}$ summer $\mathrm{EC}_{\mathrm{e}}$ levels $>8 \mathrm{dS} / \mathrm{m}$ ), waterlogged sites. However, Melilotus siculus (Turra)

9 Vitman ex B.D. Jacks._has the potential to fulfil this role, provided an appropriate Rhizobium strain can be selected. Mixtures of species and cultivars should be sown to account for high spatial variability for salinity and waterlogging. Traits for annual legume success in saline landscapes include salinity and waterlogging tolerance in germinating seedlings and mature plants, early flowering, hardseededness and delayed softening of

14 hard seeds. Establishment of regenerating seedlings is related to the timing of hardseed softening, in relation to rainfall events capable of leaching topsoil salts. It is proposed that salinity measurements to determine annual legume suitability for winter-dominant rainfall areas are made in summer or early autumn, when at their highest levels. Transects along salinity and waterlogging gradients are suggested as an alternative method to traditional plots for genotype evaluation.

20

21 Additional keywords: waterlogging, establishment, biomass, plant evaluation, plant 


\section{Introduction}

2 Large areas of southern Australia have become seriously affected by dryland salinity, caused

3 by the clearing of deep-rooted native perennial vegetation and the subsequent rise of watertables (Barrett-Lennard 2003a). The National Land and Water Resources Audit (Dolling et al. 2001) estimates that 5.7 million hectares of agricultural land in Australia are currently affected by dryland salinity or at risk from shallow water-tables, with this area expected to rise to 17 million hectares by 2050 . Many areas affected by dryland salinity are also prone to waterlogging, due to the presence of shallow water-tables. Plants growing in such

9 environments are subject to the additional challenge of hypoxia (low oxygen concentration), making plants susceptible to higher shoot concentrations of $\mathrm{Na}^{+}$and $\mathrm{Cl}^{-}$than in well-drained

11 soils, and resulting in synergistically adverse effects on plant growth and survival (Barrett-

12 Lennard 2003a). An additional feature of saline lands is their extreme spatial variability for

13 salinity, which can vary up to 10 -fold within a square metre (Rogers et al. 2005).

Over the past 10 years there has been growing interest by farmers in increasing the productivity of salt-affected land (Barrett-Lennard 2003b). Whole-farm bio-economic modelling (O’Connell et al. 2005) has demonstrated large animal production benefits and positive economic outcomes from incorporating saltland pastures into a farming system, on what was previously considered unproductive land. Saltland pastures are generally based on

19 saltbush (Atriplex species) in low rainfall areas or salt-tolerant grasses, such as puccinellia (Puccinellia ciliata Bor) or tall wheat grass (Thinopyrum ponticum (Podp.) Z.-W. Liu \& R.-C.

21 Wang, in higher rainfall areas (Barrett-Lennard 2003b). However, saline landscapes are generally infertile, due to nitrogen deficiency resulting from denitrification and the lack of a legume base (Rogers et al. 2005). Companion legumes with salinity tolerance are, therefore, required to supply nitrogen to sustain productivity of the system. Recent studies (F.A. Byrne 
and A.D. Bathgate et al., pers. comm.) have shown large economic benefits from the incorporation of legumes into saline landscapes.

Several glasshouse studies have identified differences in salinity tolerance between

4 annual legumes. West and Taylor (1981) showed that subterranean clover (Trifolium subterraneum L.) is very sensitive to salinity, with reductions in germination rates at concentrations above $70 \mathrm{~mol} / \mathrm{m}^{3} \mathrm{NaCl}$. Rogers and Noble (1991) demonstrated balansa clover (T. michelianum Savi) had a greater survival rate than subterranean clover at concentrations greater than $75 \mathrm{~mol} / \mathrm{m}^{3} \mathrm{NaCl}$ over a 4 month period, but was no more tolerant of salinity at

9 germination and emergence. Russell (1976) and Rogers et al. (1997) also showed that Persian clover (T. resupinatum L.), berseem clover (T. alexandrinum L.), woolly clover ( $T$. tomentosum L.), and snail medic (Medicago scutellata (L.) Mill.) were more salinity tolerant than subterranean clover. Recently, Rogers et al. (2006) demonstrated shoot dry matter production reductions of less than $20 \%$ for Melilotus siculus (Turra) Vitman ex B.D. Jacks. (syn. M. messanensis (L.) All.) and 5 other Melilotus species, compared to non-saline controls, when grown at $240 \mathrm{mmol} \mathrm{NaCl}$ for 28 days.

17 in glasshouse studies. Rogers and West (1993) showed that balansa clover and Moroccan

18 clover (T. isthmocarpum Brot.) had no reductions in shoot dry weight after flooding for 15

19 days, while significant reductions occurred in T. subterraneum L. var. brachycalycinum

20 (Katzn. \& Morley) Zohary and purple clover (T. purpureum Loisel.). Gibberd et al. (2001)

21 showed that among 20 Trifolium species, gland clover (T. glanduliferum Boiss.) had

22 significantly higher relative growth rates (RGR) 35 days after flooding than well drained

23 controls, while there were no RGR differences between treatments for balansa clover, Persian

24 clover, woolly clover, T. ornithopodioides L., Trifolium subterraneum L. var. yanninicum 25 (Katzn. \& Morley) Zohary and 4 other species. Conversely, significant reductions in RGR 
were observed for $T$. glomeratum L., T. hirtum All., purple clover and 8 other species. Rogers et al. (2006) also showed that Melilotus siculus had less than 20\% loss of shoot dry matter production after 28 days growth in stagnant solution, compared to aerated controls.

Balansa and Persian clovers have been widely promoted across southern Australia as pasture legumes suitable for saline soils prone to winter waterlogging (Evans and Snowball 1993; Evans and Cameron 1998; Craig 1999; Barrett-Lennard 2003b). However, their performance has been unreliable. Evans and Kearney (2003) have advocated the use of Melilotus albus Medik. for saline soils in western Victoria, while the need for better adapted

9 salt and waterlogging tolerant annual legumes has been noted by Nichols et al. (2007a).

There is limited published agronomic data on the field performance of different annual

11 legumes in saline environments, particularly for the low and medium rainfall areas of

12 southern Australia. Rogers and Bailey (1963) published salinity tolerance ratings for 6 annual

13 legumes based on observations at one field site in Western Australia, but presented no data to

14 support their claims. Evans and Snowball (1993) presented herbage data in the establishment 15 year for 13 annual legumes at a waterlogged, mildly saline site $\left(\mathrm{EC}_{\mathrm{e}} 3.3 \mathrm{dS} / \mathrm{m}\right)$ in Western

16 Australia. Hall and Evans (2001) presented establishment density and first year herbage

17 production data for 32 annual legumes on a salinity gradient in Tasmania $\left(\mathrm{EC}_{\mathrm{e}}\right.$ range 1.9 to

$1830.9 \mathrm{dS} / \mathrm{m}$ ), but did not examine performance in subsequent years. Dear et al. (2003)

19 examined the performance of 28 annual legumes at 3 waterlogged sites in New South Wales, 20 but none of them were saline (ECe less than $2 \mathrm{dS} / \mathrm{m}$ ). The study of Evans and Cameron 21 (1998) at a saline site in Victoria $\left(\mathrm{EC}_{\mathrm{e}} 10.0 \mathrm{dS} / \mathrm{m}\right)$ is the only one to have measured annual 22 legume production and persistence beyond the establishment year.

In view of the paucity of field data on the comparative performance of annual legumes 24 on saline land, a series of experiments was established by the Cooperative Research Centre for Plant-based Management of Dryland Salinity (Dear and Ewing 2007, this issue). This 
1 paper reports the herbage production and persistence over 3 years of a range of commercially

2 available and experimental annual legumes at 5 sites across southern Australia that varied in

3 extent of salinity and waterlogging. An accompanying paper (Nichols et al. $2007 b$ this issue)

4 discusses the performance of perennial legumes and grasses at the same locations, while

5 Boschma et al. (2007, this issue) discuss the performance of a range of legumes and grasses in 6 northern New South Wales.

\section{$8 \quad$ Materials and methods}

\section{Site location and characterisation}

10 Evaluation was conducted at 5 sites, chosen to represent typical saline landscapes in the low

11 to medium rainfall areas of southern Australia. Four sites were sown in 2003, comprising

12 Tammin (4 km NW of Tammin) and Duranillin (26 km S of Darkan) in Western Australia,

13 Keith (17 km W of Keith) in South Australia and Girgarre (3 km N of Girgarre) in Victoria.

14 An additional site was sown in 2004 at Cranbrook (40 km NW of Cranbrook), Western

15 Australia. Further site details and general soil descriptions are given in Table 1. A preliminary

16 evaluation site sown at Tammin in 2002 (hereafter referred to as Tammin02) was located

17 adjacent to the 2003 experiment and supplied some supplementary data. It contained the same

18 entries sown in the 2003 experiment and was subject to the same management. This site was

19 only monitored for 12 months and is not included in the analyses.

20

21

The experimental locations were subject to a mediterranean-type climate, characterised by mild, wet winters and hot dry summers. Long-term mean annual rainfall of the sites varied from $330 \mathrm{~mm}$ at Tammin ( 4 months growing season) to $530 \mathrm{~mm}$ at both Duranillin and 
Cranbrook ( 7 months growing season). Monthly rainfall data for the experimental sites was obtained from the closest Bureau of Meteorology recording station.

The Tammin site was in a former cropping paddock, while the other sites were in longterm grazing paddocks. Prior to sowing all sites had been colonised by sea barley grass (Hordeum marinum Huds.), known to inhabit saline areas due to its tolerance to both salt and waterlogging (Garthwaite et al. 2003). The Tammin site was also colonised by small leaf bluebush (Maireana brevifolia (R. Br.) Paul G. Wilson), creeping saltbush (Atriplex semibaccata $\mathrm{R}$. Br.) and curly ryegrass (Parapholis incurva (L.) C. E. Hubb.). The Duranillin site also contained water buttons (Cotula coronopifolia L.) and curly ryegrass, while much of the surrounding paddock also contained bare scalds and patches colonised by puccinellia that had been sown some 20 years earlier. The Cranbrook site was essentially a monoculture of dense sea barley grass, with a few patches of annual ryegrass (Lolium rigidum Gaudin). The Girgarre site originally contained creeping saltbush, annual ryegrass, perennial ryegrass (Lolium perenne L.), wallaby grass (Austrodanthonia spp.) and puccinellia. It was strongly sodic below $10 \mathrm{~cm}$ and became increasing alkaline with depth (data not presented). At Keith puccinellia was the dominant species, with a smaller proportion of sea barley grass and capeweed (Arctotheca calendula (L.) Levyns).

Soil attributes in the top $10 \mathrm{~cm}$ were determined at each site by taking a minimum of 10 random soil cores, which were then bulked. All sites were measured at least once in winter and once in summer to obtain maximum and minimum soil surface salinity levels. Monthly soil sampling was conducted between March 2003 and March 2005 at Keith and between

February 2003 and October 2005 at Girgarre to monitor changes in soil surface salinity levels.

Soil salinity levels were estimated by the electrical conductivities of aqueous solutions

$4\left(\mathrm{EC}_{1: 5}\right)$, which were converted to an estimate of saturated paste extracts $\left(\mathrm{EC}_{\mathrm{e}}\right)$, using the relationships of Slavich and Petterson (1993). Soil samples from the Western Australian sites 
1 were analysed by CSBP Pty Ltd, the Keith site was analysed by the South Australian Soil and

2 Plant Analysis Service (SASPAS) and the Girgarre site by the Department of Primary

3 Industries Victoria. Salinity levels of individual plots at Tammin were estimated with an

4 EM38 instrument in early August 2003 and late September 2005. Measurements were

5 converted to $\mathrm{EC}_{1: 5}$ by calibrating against 6 soil samples $\left(\mathrm{r}^{2}=0.61\right.$ in 2003 and $\mathrm{r}^{2}=0.75$ in

6 2005). In order to compare soil drainage and texture between sites, the rating systems of

$7 \quad$ McDonald et al. (1990) were used.

8

9 Species evaluated

10 Forty two annual legumes from 33 species originating in the Mediterranean basin (Nichols et

11 al. 2007a) were evaluated (Table 2). Entries consisted of either single genotypes or

12 composites of 2 - 4 genotypes mixed in equal proportions. For simplicity, composites of

13 genotypes are referred to by the species name, while single genotypes are referred to by

14 species and genotype name. Species were selected either on the basis of purported salinity

15 tolerance (Rogers et al. 2005) or on the basis of being new or important pasture cultivars used

16 in southern Australian agriculture for which little or no information on relative salinity

17 tolerance is known. Frontier balansa clover, a widely recognised industry standard for saline

18 pastures (Barrett-Lennard 2003b; Craig et al. 2000), was used as a common control at all

19 sites, while subterranean clover, a species known to be susceptible to salinity (West and

20 Taylor 1981), was included as a plant indicator of salinity.

21 Seeds for all experiments were obtained from the Australian Medicago Genetic

22 Resource Centre, operated by the South Australian Research and Development Institute.

23 Seeds were tested for viability and sowing rates were adjusted to ensure an equivalent of at

24 least $80 \%$ germinability. Seeds were slurry inoculated immediately prior to sowing with the

25 appropriate strain of Rhizobium, where known, or with a mixture of best-bet strains.

Formatted: Right: $0.63 \mathrm{~cm}$ 

importation into Australia or from specific importation into Western Australia due to high weed potential under Australian Quarantine Inspection Service (AQIS) or Western Australian

4 Quarantine Inspection Service (WAQIS) regulations, respectively. At the commencement of the evaluation program, these species were already held in Australian Genetic Resource Centre collections and were available for evaluation under regulations existing at the time.

7 New protocols subsequently developed by the CRC for Plant-based Management of Dryland

8 Salinity (Stone 2007, this issue) will ensure distribution of these species will not occur in the

9 future.

\section{Insert Table 2 near here}

11

\section{Experimental design and management}

13 Each experiment consisted of a row-column design with 5 replicates. Plot dimensions at

14 Tammin, Duranillin, Girgarre and Keith were $2 \mathrm{~m}$ x $1 \mathrm{~m}$, with $1.5 \mathrm{~m}$ buffers between plots, while at Cranbrook they were $5 \mathrm{~m} \times 2 \mathrm{~m}$ with no buffer strips between plots.

Experimental sites were prepared by cultivation and knock-down herbicides to provide

17 a smooth, weed-free seed bed. At Keith, trifluralin (480 g a.i./L) was applied pre-sowing at a rate of $1.5 \mathrm{~L} / \mathrm{ha}$. The Cranbrook and Girgarre plots were drilled in by cone seeder. Seed at the other sites was hand broadcast onto plots and lightly raked. Sowing dates were 11 May in 2002 (Tammin02), 20 May (Duranillin), 27 May (Tammin), 5 June (Girgarre) and 24 June (Keith) in 2003 and 10 June (Cranbrook) in 2004. A standard sowing rate of $10 \mathrm{~kg} / \mathrm{ha}$ of germinable seed was used for all species. Fertiliser application at sowing varied between sites. At the Western Australian sites this consisted of $250 \mathrm{~kg} / \mathrm{ha}$ of a 50:50 mix of superphosphate with molybdenum (Mo), copper $(\mathrm{Cu})$ and zinc $(\mathrm{Zn})(9.0 \% \mathrm{P}, 10.1 . \% \mathrm{~S}, 0.6 \% \mathrm{Cu}, 0.3 \% \mathrm{Zn}$ and $0.06 \% \mathrm{Mo}$ ) and single superphosphate with potash $(6.8 \% \mathrm{P}, 12.4 \% \mathrm{~K}$ and $8.3 \% \mathrm{~S})$, at 
1 Girgarre it consisted of $100 \mathrm{~kg} / \mathrm{ha}$ of single superphosphate $(8.8 \% \mathrm{P}, 11 \% \mathrm{~S})$ and at Keith it was $100 \mathrm{~kg} / \mathrm{ha}$ of single superphosphate and $50 \mathrm{~kg} / \mathrm{ha}$ of potash with $1 \%$ copper and $1 \%$ zinc. Bifenthrin ( $80 \mathrm{~g}$ a.i./L) was applied at a rate of $100 \mathrm{~mL} / \mathrm{ha}$ immediately after sowing for

4 control of redlegged earth mite (Halotydeus destructor (Tucker)) at Tammin, Duranillin and

5 Cranbrook, while alpha-cypermethrin ( $25 \mathrm{~g}$ a.i./L) was applied 6 weeks after sowing at a rate 6 of $100 \mathrm{~mL} / \mathrm{ha}$ at Keith and at $75 \mathrm{~mL} / \mathrm{ha}$ at Girgarre.

Herbicides were used where appropriate for weed control in the first year of

8 experiments to maximise the chances of successful establishment. Grass weeds were removed 9 using $250 \mathrm{~mL} / \mathrm{ha}$ of clethodim (240 g a.i./L) at Tammin, Duranillin and Cranbrook during 10 winter of the establishment year and with fluazifop ( $212 \mathrm{~g}$ a.i./L) at $0.5 \mathrm{~mL} / \mathrm{ha}$ at Girgarre. In 11 January and February 2004, the Girgarre experiment was sprayed with 1.0 L/ha of

12 glyphosphate (540 g a.i./L ) and with $2.0 \mathrm{~L} / \mathrm{ha}$ of bromoxynil (200 $\mathrm{g}$ a.i./L) and MCPA (200 g

13 a.i./L) to control summer-active broadleaf weeds. Some shrubby species, notably creeping

14 saltbush, were removed by hand in the second year at Tammin. Weeds in individual plots at

15 Girgarre were also controlled by spot spraying with glyphosphate (540 g a.i./L) or selective

16 hand-weeding. Buffer strips between plots were maintained by applying $2.0 \mathrm{~L} / \mathrm{ha}$ of

17 glyphosphate (540 g a.i./L) each winter at Tammin, Girgarre and Keith and were mown in

18 winter and early spring at Duranillin and Cranbrook.

19 Maintenance dressings were applied in winter of the second and third years to the

20 Western Australian experiments (150 kg/ha of single superphosphate with potash) and at

21 Girgarre (200 kg/ha of single superphosphate), while the Keith site received $100 \mathrm{~kg} / \mathrm{ha}$ of

22 single superphosphate and $50 \mathrm{~kg} / \mathrm{ha}$ of potash with $1 \%$ copper and $1 \%$ zinc in August each

23 year. Redlegged earth mites were controlled at Keith in autumn of the second and third years

24 by applying $100 \mathrm{~mL} /$ ha of alpha-cypermethrin (100 $\mathrm{g}$ a.i./L). 
Plots remained undefoliated during the growing season. However, excess dry matter was generally removed from plots during early summer. Seed was first dislodged from stems

3 by raking or trampling to avoid seed transfer between plots. The experiments in Western

4 Australia were grazed by sheep, in common with the surrounding paddock, during the remainder of summer, while dry residues were removed each summer by raking at Keith. The exceptions were the Girgarre site, which remained ungrazed and the Cranbrook site, which was not grazed over the second summer.

\section{$9 \quad$ Plant measurements}

11 determined by counting the number of emerged seedlings in random quadrats 4 - 6 weeks

12 after sowing. Densities of regenerating seedlings were measured in autumn or early winter of

13 each year 4 - 6 weeks after the opening rains to the season. Seedlings were counted in 2

14 quadrats $\left(25 \mathrm{dm}^{2}\right)$ per plot at the Western Australian sites, 4 quadrats $\left(1 \mathrm{dm}^{2}\right)$ at Keith and 2 quadrats $\left(12.5 \mathrm{dm}^{2}\right)$ at Girgarre.

Biomass and composition. Biomass production of sown species was estimated each

17 spring. First year measurements were made at Tammin, Keith, Cranbrook, Duranillin and

18 Girgarre on 18 Sept., 17 Oct., 19 Oct., 20 Oct. and 23 Oct., respectively. Second year

19 measurements were conducted on 23 Aug., 16 Sept., 21 Sept., 19 Oct. and 10 Nov. at

20 Cranbrook, Duranillin, Tammin, Girgarre and Keith, respectively, while third year

21 measurements were conducted on 16 Sept. at Duranillin and 19 Sept. at Tammin. For most

22 measurements total plot herbage production was estimated visually using a continuous rating

23 scale and calibrated against a minimum of 15 quadrats cut to ground level. The percentage of

24 sown species in each plot was estimated visually at the same time. Quadrat samples were sorted into sown and non-sown components and oven-dried at $80^{\circ} \mathrm{C}$ for at least 24 hours. 
1 Total plot herbage yields $(\mathrm{kg} / \mathrm{ha})$ were determined by regression and converted to biomass of sown species. Regression coefficients varied from $r^{2}=0.53$ to 0.98 , with most $r^{2}$ values being greater than 0.80 . Regressions for the percentage of sown species were calculated as checks of

4 visual scores. These all had $\mathrm{r}^{2}$ values greater than 0.85 . At Keith in 2004 and Duranillin in 2004 and 2005, quadrats were cut to ground level for each plot, sorted into sown and nonsown components, dried and weighed. Third year non-calibrated biomass ratings, using a 0-10 scale, were also conducted at Girgarre on 10 Oct.

Flowering time and seed production. Flowering times were estimated in 2002 at the

9 Tammin02 site and in 2003 at Keith. Only a single replicate was scored at Tammin02, while

10 all 5 replicates were scored at Keith. Time to first flowering was deemed to be the number of

11 days from sowing to when $50 \%$ of plants had at least one open flower. Assessments were

12 made weekly. An index of seed production was made on the annual legumes at Tammin,

13 Cranbrook and Keith in the first summer following sowing. Ten pods were examined per plot.

14 A graded scale of $0-5$ was used for both seed set per pod and pod density per plot (where $0=$ no seed or pod, $5=$ highest value). The two figures were multiplied to provide a maximum score of 25 .

17 Waterlogging tolerance and nodulation. The plots at Keith were rated on 16 Sept. (11 weeks

18 after sowing) for healthiness and survival, as a measure of waterlogging tolerance, following

197 weeks of inundation. ECe levels of less than $2 \mathrm{dS} / \mathrm{m}$ during this period (figure 1) allowed this assessment to be conducted without major confounding effects of salinity. A graded scale

21 of $0-5$ was used for plant survival and health, where $0=$ all plants dead and $5=$ all plants green and healthy. Scores for the presence and effectiveness of rhizobial nodulation were also made at Keith on the same day. Two plants were randomly selected from each plot. Individual

24 plants were carefully dug up to avoid nodules being knocked off the roots and immediately washed in water. The total root system was removed and scored for nodulation on the tap and 
1 lateral roots using a $0-3$ rating scale, where $0=$ no nodules, $1=$ small white nodules only, $2=$

2 less than 5 pink nodules and $3=$ at least 5 pink nodules per plant.

\section{$4 \quad$ Data analysis}

5 The data for most measurements at each site tended to be highly variable, due to the variability for soil salinity and waterlogging common to saline sites. Attribution of this variation to measurement error or site variability was difficult. In order to stabilise the variance, $\log _{10}$ transformations were used for seedling density and herbage production data,

9 while square root transformations were used for seed production index measurements. In both

10 cases, the value 1 was added to the data prior to transformation. Transformations were not

11 made for nodulation and waterlogging tolerance ratings, Year 3 herbage production ratings at

12 Girgarre, and measurements of flowering time. Outliers which were more than 3 standard

13 deviations from the mean were removed from the data. This ranged from 0 - 3 measurements

14 per variable at each site.

Pearson correlations were conducted between all combinations of flowering time, seed production index and second year regeneration density for each species at Keith and Tammin.

17 Flowering time data from the Tammin02 site was used in the Tammin comparisons. Mean

18 species values were used in each case $(\mathrm{n}=21$ at Keith and $\mathrm{n}=32$ at Tammin). Pearson

19 correlations were conducted at Tammin between EM38 horizontal readings of individual plots

20 and corresponding transformed plant measurements $(n=160)$. In order to ascertain whether

21 species success was related to site differences, Pearson correlations $(n=5)$ were conducted

22 between third year plant density (log transformed) and the soil and rainfall measurements

23 (Tables 1 and 3, respectively) from each site for the 12 species common to at least four sites.

24 For Girgarre, third year spring herbage production ratings were used instead. 
All analyses were conducted using GENSTAT ( $9^{\text {th }}$ edition $)$. Analyses of Variance

2 (ANOVA) and spatial analyses (using several models with REML) were attempted on

3 transformed variables, with the latter analyses used to account for measurable trends or spatial

4 variability within sites. Comparisons between species did not change substantially when using

5 a spatial model compared with a simple randomised block model (with the terms Blocks $=$

6 replicates and Treatment $=$ species). Consequently, randomised block analyses are presented

7 for all data. Least significant differences (1.s.d.s) at the 5\% probability level were also

8 calculated. Multiple zero values at a site were included in the analysis, even though it was

9 recognised that this may artificially lower 1.s.d.s. However, in cases where only one species

10 had a positive value for a measurement, data were not analysed. Instead, summary statistics of

11 the raw mean and standard deviation for that species are presented.

Formal genotype $\mathrm{x}$ environment $(\mathrm{G} \times \mathrm{E})$ analyses were not attempted. The purpose of

13 such analyses is usually to identify genotypes adapted to a wide range of environments. In this

14 case, the expectation was that large $\mathrm{G} \times \mathrm{E}$ effects would occur, due to the large differences in

15 site characteristics and in the levels of salinity and waterlogging tolerances of species.

16 For simplicity, annual legume performance is compared with Frontier balansa clover.

17 Raw data is also presented to give biological meaning to the results.

\section{Results}

\section{Seasonal conditions}

20 Rainfall recorded at each site during the experimental period is shown in Table 3, while long-

21 term mean annual rainfall data are shown in Table 1. The Tammin experiment experienced no rain for three weeks following sowing, resulting in sub-optimal establishment of some species. The remainder of the season was favourable for growth until early October. Below-

24 average rainfall fell at Tammin in both 2004 and 2005. Dry spring conditions resulted in 
1 senescence of most annual legumes by September 30 in both these years. No surface waterlogging or inundation was apparent during the experiment.

Rainfall at Duranillin was below average in 2003 and 2004, but was similar to the long-

4 term average in 2005. However, the soil surface remained wet with extended periods of inundation from mid-June to mid-October in 2003 and 2004 and from early May to midOctober in 2005. At Cranbrook the 2004 sowing year had below average rainfall, but soil moisture conditions were favourable for growth until late October. Rainfall in 2005 was well above average, with opening season rains in late March and soil surface moisture remaining

9 until mid-November, while the 2006 season had below average rainfall. Plots were waterlogged in August 2005, including a 7 day period of inundation, but were free draining at

11 other times. At Girgarre rainfall was below average each year, although the 2004 season was

12 prolonged until early December. Waterlogging, with periods of inundation of 7-10 days,

13 occurred in late August in both 2004 and 2005. Rainfall at Keith was similar to the average in

142003 and below average in 2004 and 2005. The site was inundated in 2003 for 7 weeks from early August and for 3-4 weeks during winter and early spring in 2004 and 2005.

16

17
Insert Table 3 here

\section{Soil surface salinity}

Soil surface electrical conductivities varied markedly between sites and between seasons within sites (Table 1). Using the broad categories of Rogers et al. (2005), Duranillin, Keith and Tammin were highly saline in summer $\left(\mathrm{EC}_{\mathrm{e}}>8 \mathrm{dS} / \mathrm{m}\right)$, while Cranbrook and Girgarre were moderately saline $\left(\mathrm{EC}_{\mathrm{e}} 4-8 \mathrm{dS} / \mathrm{m}\right)$. However, in winter Duranillin had moderate salinity, Tammin and Cranbrook had low salinity $\left(\mathrm{EC}_{\mathrm{e}} 2-4 \mathrm{dS} / \mathrm{m}\right)$ and Girgarre and Keith were non-saline $\left(\mathrm{EC}_{\mathrm{e}}<2 \mathrm{dS} / \mathrm{m}\right)$. Surface salinity varied in response to changes in soil moisture conditions. It tended to decline following heavy rainfall, due to leaching of salts, and 
1 tended to increase as the soil surface dried out. This was particularly evident on the sandy soil

2 at Keith (Fig. 1) and to a lesser extent on the light clay soil at Girgarre (Fig. 2).

Within-site variability for salinity was evident at Tammin, where plot $\mathrm{EC}_{\mathrm{e}}$ values ranged from 0.80 - $4.21 \mathrm{dS} / \mathrm{m}$, when measured in early August 2003, and 1.95 - $5.15 \mathrm{dS} / \mathrm{m}$, when measured in late September 2005. This was also evident at Girgarre, where $\mathrm{EC}_{\mathrm{e}}$ levels varied from 4.1 - 10.7, when measured in August 2004, and from 2.9 dS/m to $8.1 \mathrm{dS} / \mathrm{m}$, when measured in December 2004. It is likely that high variability for salinity occurred at the other sites as well.

11 Plant survival, production and persistence

12 Establishment densities were poor at Duranillin and relatively low at Tammin and Girgarre, but were higher at Cranbrook and Keith (Table 4). Highly significant species differences were found at each site. No species had significantly greater seedling densities than Frontier at

15 Cranbrook or Girgarre, while Paradana balansa clover, Lotus hispidus DC. and T.

16 ornithopodioides had higher densities at Tammin and Bolta balansa clover, Trifolium

17 isthmocarpum, T. ornithopodioides and T. tomentosum had higher densities at Keith. At

18 Duranillin only Paradana balansa clover and Melilotus siculus had more than 30 plants $/ \mathrm{m}^{2}$. densities of the 5 replicates of Frontier ranged from $0-103$ plants $/ \mathrm{m}^{2}$ at Girgarre and $15-100$ plants $/ \mathrm{m}^{2}$ at Tammin. Similar within-site variability was seen at each site for other variables. 
1 speciosus Durieu produced no nodules at all, while T. alexandrinum only produced small

2 white nodules and M. neopolitanus Ten. produced very few pink nodules. Plant health ratings

3 at Keith, following 7 weeks inundation during the first winter (in the presence of salinity

4 levels $<2 \mathrm{dS} / \mathrm{m}$ ), are shown in Table 5. The health of Melilotus speciosus, M. italicus (L.)

$5 \quad$ Lam., M. neopolitanus, M. sulcatus Desf. (syn. M. sulcatus Desf. ssp. brachystachys (Brot.)

6 P.Fourn.) and Trigonella balansae Boiss. \& Reut. SA5045 was very poor, while $T$.

7 alexandrinum, M. albus, M. infestus Guss., Scimitar burr medic (Medicago polymorpha L.)

8 and Trikkala subterranean clover all had lower ratings than Frontier. It should be noted that

9 the 4 species with poorest nodulation also had poor health. The lower health score for

10 Trikkala subterranean clover than Frontier presumably reflected its sensitivity to the low level

11 of salinity.

12

13

14

15

16

17 .

\section{Insert Table 5 near here}

Biomass differences between species in the first spring were highly significant at each site (Table 6). Mean herbage production was very low at Tammin, Duranillin and Girgarre and was highest at Cranbrook. First year production of Frontier balansa clover was among the highest of all species, with no species producing significantly more biomass at any site.

Conversely, 13 species produced significantly less biomass at Tammin, 24 at Duranillin, 9 at Cranbrook, 4 at Girgarre and all but Persian clover cv. Persian Prolific produced less at Keith.

Of the 32 species sown at more than one site, 11 (Biserrula pelecinus L. cv. Casbah, Lotus

halophilus Boiss. \& Spruner, L. hispidus, Ornithopus pinnatus (Mill.) Druce cv. Jebala, $O$.

sativus Brot. cv. Margurita, Trifolium alexandrinum, T. glanduliferum cv. Prima, $T$.

incarnatum L. cv. Caprera, T. purpureum cv. Paratta, T. sqamosum L. and T. subterraneum

var. subterraneum (Katzn. \& Morley) Zohary) cv. Dalkeith produced significantly less than

5 Frontier in all experiments. Of note at the most favourable site of Cranbrook was the poor 

subterranean clover.

4 Keith, as was Paradana balansa clover at the 2 sites it was sown. The performance of Persian clover cultivars Nitro Plus and Persian Prolific contrasted. Persian Prolific produced similar levels to Frontier at each of the 4 sites it was tested, whereas Nitro Plus produced less herbage than Frontier at Duranillin, Girgarre and Keith. Scimitar burr medic performed similarly to Frontier at all sites, except Keith, while Santiago and Cavalier burr medics and Caliph barrel

9 medic produced similar biomass at Tammin. Trifolium isthmocarpum also produced similar biomass to Frontier at 3 sites.

11

12

\section{Insert Table 6 near here}

Time to first flowering varied widely between species, ranging from 95 to more than 135 days at Keith and from 74 days to more than 112 days in the Tammin02 experiment (Table 7). Frontier balansa clover was among the earliest flowering species. At Keith only Scimitar and T. tomentosum flowered earlier than Frontier, while in the Tammin02 experiment Frontier flowered about a week later than Scimitar and Santiago burr medics, Sava snail medic and Caliph barrel medic (Medicago truncatula Gaertn.). Species in the Tammin02 experiment that had not flowered by 1 Oct. (112 days after sowing) included Bolta balansa clover, Lotus hispidus, M. arabica (L.) Huds., Trifolium alexandrinum, T. clusii Godr. \& Gren., T. squamosum, T. ornithopodioides, T. purpureum cv. Paratta and T. incarnatum cv. Caprera. While flowering time was not recorded in the 2003-sown Tammin experiment, it was noted that L. hispidus, M. arabica, T. alexandrinum, T. squamosum. T. ornithopodioides and T. incarnatum cv. Caprera had not yet flowered by 30 Sept. (126 days after sowing). At Keith, 
14 species (Melilotus albus, M. infestus, M. speciosus and T. alexandrinum had not flowered

2 by 11 June (135 days after sowing).

3

4

\section{Insert Table 7 near here}

There were highly significant species effects for seed production index at the 3 sites where this was estimated (Table 7). No species had a significantly higher index than Frontier balansa clover at any site. At Cranbrook only Bolta balansa clover and Cavalier burr medic had a similar index to Frontier, while T. ornithopodioides failed to set seed. At Tammin only T. tomentosum and T. spumosum L. had a similar seed production index to Frontier, while 12 species failed to set seed. These included all those that had failed to flower by 30 Sept. At Keith 7 species had similar seed production indices to Frontier, while 6 failed to set seed. Three of the 4 species at Keith that had not flowered by 6 Nov. failed to set seed, although the fourth species, Melilotus infestus, had a high seed production index. Among the other Melilotus species tested at Keith, M. siculus, M. indicus (L.) All., M. infestus and M. segetalis (Brot.) Ser. (syn. M. sulcatus Desf. ssp. segetalis (Brot.) P.Fourn.) all had a high seed production index, while M.albus, M. italicus., M. neopolitanus, M. speciosus and M. sulcatus either failed to set seed or had a low seed production index.

Mean regeneration densities in the autumn-winter of year 2 were low at each site, particularly at Duranillin and Girgarre (Table 8). At Girgarre, this may have been attributable to lack of defoliation over summer. However, highly significant species effects were again evident at each site. At Duranillin, regeneration of all species was zero or negligible, apart from Melilotus siculus, while 5 of the 11 species, including Frontier balansa clover, had no regeneration at Girgarre. Frontier regeneration was poor at Tammin and Keith, while at Cranbrook it had the highest regeneration density. Annual legumes with superior second year regeneration to Frontier balansa clover were present at each site, apart from Cranbrook. $M$. 
siculus had higher regeneration densities at both Duranillin and Keith, while regeneration of

2 T. ornithopodioides was also higher at Keith. Scimitar burr medic had significantly higher

3 densities at both Tammin and Girgarre, while regeneration of Cavalier and Santiago burr

4 medics, Caliph barrel medic, Sava snail medic and T. tomentosum was also higher at Tammin.

5 At Girgarre regeneration of Trikkala subterranean clover was also higher than Frontier.

6

7

At Keith a significant negative correlation was found between seed production index and flowering time $(\mathrm{r}=-0.46, P<0.05)$, while a significant positive correlation was found between seed production index and second year regeneration density $(\mathrm{r}=0.57, P<0.01)$.

However, there was no correlation between flowering time and regeneration density.

Contrasting results were found at Tammin. Somewhat surprisingly there was no correlation between seed production index and flowering time, or between seed production index and second year regeneration density. However, there was a highly significant correlation $(r=-$ $0.60, P<0.001)$ between flowering time and regeneration density.

Herbage production in the second spring was much higher at Cranbrook than the other sites (Table 9). Frontier balansa clover produced the most biomass at Cranbrook with $7.6 \mathrm{t} / \mathrm{ha}$ of biomass (raw data), but was not significantly different to 7 other species. However, Frontier yielded very little at Tammin and Duranillin and failed to produce any biomass at Girgarre and Keith. The highly significant species effects observed at each site generally reflected regeneration density differences. Scimitar burr medic produced the most biomass at

Tammin, but was not significantly different from Cavalier and Santiago burr medics, Caliph barrel medic, Sava snail medic and T. tomentosum. Scimitar also produced significantly more herbage than Frontier at Girgarre and Keith. Melilotus siculus was the best performing species at the waterlogged sites of Duranillin and Keith, particularly at Duranillin, where it was 
1 clearly the most outstanding species. It is noteworthy that very poor rhizobial nodulation was observed during the second (and third) years on M. siculus at Duranillin, Keith and

3 Cranbrook, with less than $10 \%$ of regenerating plants forming effective nodules. Unnodulated

4 plants were severely stunted and failed to set seed.

6

\section{Insert Table 9 near here}

Year 3 regeneration densities (Table 10) and spring herbage production (Table 11)

followed similar trends as for year 2. After 3 years it was apparent that the most persistent and/or productive species were: Scimitar, Cavalier and Santiago burr medics, Caliph barrel medic and T. tomentosum at Tammin; Melilotus siculus at Duranillin; Frontier and Bolta balansa clovers, Persian Prolific Persian clover, Scimitar and Cavalier burr medics, $M$. siculus and T. isthmocarpum at Cranbrook; Trikkala subterranean clover at Girgarre; and M. siculus, M. infestus, Scimitar burr medic and T. ornithopodioides at Keith.

\section{Insert Tables 10 and 11 near here}

\section{Relationships between plant performance and site attributes}

At Tammin establishment density was significantly reduced with increasing August EM38 horizontal readings $(\mathrm{r}=-0.29, P<0.001)$. Spring herbage production in the first year also decreased with increasing EM38 horizontal readings in August $(\mathrm{r}=-0.33, P<0.001)$ and in September $(\mathrm{r}=-0.22, P<0.01)$. However, there were no significant correlations between soil salinity levels and any subsequent plant measurements.

In order to ascertain whether species success could be related to site differences, relationships were examined between third year plant density (Table 10) and the soil and rainfall measurements (Tables 1 and 3, respectively) from each site for the 12 species common to at least 4 sites. For Girgarre, third year spring herbage production ratings (Table 
1 11) were used instead. In spite of the small 5-site dataset, some significant correlations were

2 found. High Melilotus siculus density was associated with poor drainage $(\mathrm{r}=-0.97, P<0.05)$,

3 high summer $\mathrm{EC}_{\mathrm{e}}$ values $(\mathrm{r}=0.95, P<0.05)$ and sandy soils $(\mathrm{r}=-0.96, P<0.05)$, high $M$.

4 sulcatus density was associated with high May-November rainfall in year $1(\mathrm{r}=0.90, P$

$5<0.05)$ and high Trikkala density was associated with high total rainfall in year $2(\mathrm{r}=0.93, P$

$6<0.05)$, while $T$. tomentosum density increased with increasing $\mathrm{pH}(\mathrm{r}=0.88, P<0.05)$. No

7 other significant correlations were found.

8 Discussion

$9 \quad$ Coping with saline environments

10 Saline landscapes are difficult environments for annual plants. These experiments, along with 11 those of Smith and Stoneman (1970), showed considerable seasonal changes in soil salinity

12 levels within the top $10 \mathrm{~cm}$. Suitable species need to have mechanisms to cope with salinity

13 stress as both seedlings and mature plants. The year of sowing presents the least problems. If

14 sowing occurs after rainfall has leached surface salts to lower depths, germination can occur

15 under relatively favourable conditions. In this situation, only the most salt-sensitive species

16 fail to establish. Soil surface salinity then increases during spring, as soil moisture declines,

17 and reaches a maximum over summer and autumn. The timing of the first autumn rainfall

18 sufficient to germinate regenerating pasture seeds, therefore, coincides with the highest soil

19 surface salinity levels. If these rains are sufficient to leach salts from the soil surface,

20 germination will again occur in soil with relatively low salinity and present establishment

21 difficulties only to the most salt-sensitive species. However, if these rains are sufficient for

22 germination but insufficient to leach salts, high seedling losses will occur for all but the most

23 salt-tolerant species. For adaptation to saline environments, annuals must have either high

24 salinity tolerance as seedlings or mechanisms to avoid germination at times of high salinity. 
Waterlogging and inundation pose additional stresses on many saline sites and resulted in the poor performance of most species at Duranillin and Keith. Plant growth and survival at these sites would have been compromised by the lack of oxygen to the roots and also by

4 synergistic interactions with salinity to further increase shoot concentrations of $\mathrm{Na}^{+}$and $\mathrm{Cl}^{-}$ (Barrett-Lennard 2003a; Rogers et al. 2005). For adaptation to such waterlogged, saline environments, plants require additional mechanisms to cope with waterlogging.

Annual pasture legumes in saline landscapes also need the same adaptations to climate,

8 soil type (particularly $\mathrm{pH}$ and texture) and farming systems as those adapted to non-saline

9 land. Two important factors are flowering time and seed dormancy. Appropriate flowering

10 time, to balance the optimisation of both biomass accumulation in the vegetative phase and

11 seed production prior to the onset of summer drought, is critical for persistence (Ehrman and

12 Cocks 1996). In saline environments rising salinity levels in mid-late spring effectively

13 reduce the time for seed set, compared to non-saline environments in the same locality. Early

14 flowering is a salinity avoidance mechanism to counter this (Craig et al. 2000). hardseededness, to spread the risk of germination over time (Norman et al. 1998). The role of

17 hardseededness for persistence after cropping or poor seed setting seasons is well recognised

18 (Taylor et al. 1991). It is also likely to be a particularly important trait for persistence in saline

19 environments, with their high risks to germination. The timing of hardseed softening over the summer-autumn period to avoid seedling losses from false breaks to the season (germinationinducing rainfall events followed by death from drought) has been shown to be important for annual legume persistence (Norman et al. 1998, 2006; Loi et al. 2005) and is also likely to be important on saline land.

24 
Subterranean, balansa and Persian clovers. Balansa and Persian clover and the yanninicum subspecies of subterranean clover are well known for their high tolerance of

4 waterlogging (Rogers and West 1993; Dear et al. 2003). However, they failed to persist at the waterlogged sites of Duranillin and Keith. Clearly, the presence of salinity at these sites had a major impact on their growth and survival. Subterranean clover in particular was highly susceptible to salinity in these experiments, confirming previous glasshouse results (West and Taylor 1981; Rogers and Noble 1991). Trikkala only survived at the 2 least saline sites, while

9 Dalkeith, widely sown in the Tammin district on non-saline land, failed to establish at the

10 Tammin site. Balansa clover, Persian clover and Trikkala subterranean clover also performed

11 relatively poorly at 2 mildly saline, non-waterlogged sites in northern New South Wales

12 (Boschma et al. 2007, this issue). The poor performance of Trikkala in their experiments was

13 largely attributed to its very low salinity tolerance.

The variable performance of balansa and Persian clovers between sites and between years within sites accords with observations of many farmers on saline land. In the establishment year they were the most productive species at each site, as previously demonstrated by Evans and Snowball (1993). However, they only persisted at the least saline site of Cranbrook, where they were highly productive. The much greater biomass production of balansa clover than subterranean clover in the year of sowing is consistent with glasshouse results of Rogers and Noble (1991), who demonstrated a higher tolerance in balansa clover. balansa clover on saline sites. A second reason may be its rapid hardseed breakdown over the summer-autumn period. Loi et al. (2005) showed that under Western Australian non-saline

24 field conditions, the majority of seed softening in Frontier balansa clover occurs by mid- 
rains of insufficient intensity to leach salts from the topsoil. This situation is likely to have resulted in poor second year balansa clover regeneration at Tammin, Duranillin, Girgarre and

3 Keith. By contrast, the high second year balansa clover regeneration density at Cranbrook

4 followed $100 \mathrm{~mm}$ in late March, which would have leached salts from the topsoil and provided very favourable conditions for germination and seedling establishment. Thus, it appears that regeneration density of balansa clover is dependent on the intensity and timing of rainfall events and their effect on leaching salts from the topsoil. While less is known about the salinity response and hardseed breakdown pattern of Persian clover, the similarity in field

9 performance to balansa clover suggests similar behaviour.

There was some evidence of genotype differences for seedling salinity tolerance in

11 balansa and Persian clovers. Paradana balansa clover establishment densities were higher than

12 Frontier at Tammin and Duranillin, while Bolta densities were higher than Frontier at Keith,

13 but not at the other sites. Persian Prolific Persian clover densities were higher than Nitro Plus

14 at Tammin and Duranillin and Cranbrook. Further work is needed to confirm whether these results were attributable to differences in salinity tolerance. Other agronomic factors, particularly flowering time, were also important for determining relative cultivar success. The

17 advantage of early flowering in a low rainfall environment was readily apparent at Tammin,

18 where Frontier balansa clover produced more seed and persisted more strongly than the later

19 flowering cultivars Paradana and Bolta and the early flowering Persian clover SA33804 persisted more strongly than the later flowering cultivars Persian Prolific and Nitro Plus. Annual medics. These experiments demonstrated the excellent performance of burr medics, particularly the recently released cultivars Scimitar and Cavalier, on the moderately acid to neutral soils in these experiments. Burr medics are commonly naturalised on land

24 subject to salinity, but their recognition as a species for deliberate sowing on saline land has not been reported before. Their performance was particularly impressive on the well-drained 
sites of Tammin, Cranbrook and Girgarre, while the waterlogged sites of Keith and Duranillin gave contrasting results. Although Scimitar persisted at Keith, observations from other sites prone to waterlogging and inundation (AD Craig, unpublished data) suggest it is best suited to

4 saline land not subject to prolonged waterlogging. Scimitar burr medic was also the most persistent and productive annual legume at two mildly saline sites in northern New South Wales (Boschma et al. 2007, this issue).

It is worth noting that Scimitar, Cavalier and Santiago burr medics were selected for 8 productivity and persistence under non-saline conditions and it is somewhat fortuitous that

9 they also perform well on saline land. One reason may be due to be their delay in softening of 10 hardseeds until mid-late autumn (Taylor 1996). This would act as a salt avoidance mechanism 11 to defer germination until late autumn, when the expectation of rains capable of leaching salts 12 from the topsoil is higher. A higher salt tolerance than balansa clover at germination (AD

13 Craig, unpublished data; PGH Nichols et al., unpublished data) and as mature plants (MJ

14 Rogers, unpublished data) is also likely to contribute to its success.

Of the other annual medics evaluated, Caliph barrel medic performed well at Tammin and could be used in mixtures with burr medics on heavy neutral to alkaline soils in low rainfall areas. Sava snail medic was less persistent than the other medics and does not appear to offer many advantages. The $M$. arabica bulk population evaluated was too late flowering to set seed in the test environments, but the species does not appear to offer any advantages to burr and barrel medics on saline land.

Melilotus species. Melilotus siculus appears to have considerable potential as a new species for saline soils prone to waterlogging. It was the only annual legume to survive beyond the first year at Duranillin and was more persistent than balansa and Persian clovers at

24 Keith. At the less saline site of Cranbrook, it was also as persistent as balansa clover. 
1 These results are consistent with the laboratory results of Rogers et al. (2006), who showed that mature $M$. siculus plants have greater salinity tolerance than balansa clover and similar waterlogging tolerance. Maranon et al. (1989) also showed that M. siculus has greater

4 seedling tolerance of salinity than $M$. indicus and $M$. segetalis, while preliminary data ( $\mathrm{P}$

5 Nichols et al. and A Craig, unpublished data) indicates it has greater seedling tolerance than 6 burr medics.

Melilotus siculus offers good prospects for commercialisation as a new species to agriculture. It is known to inhabit saline marshy areas of the Mediterranean basin (Maranon et

9 al. 1989) and is naturalised in similar environments in southern Australia (Jeans 1996; Paczkowska and Chapman 2000). M. siculus has a major advantage over other Melilotus species by having negligible levels of coumarins (Stevenson 1969), which can be converted into dicoumarol and cause a haemorrhagic condition in livestock when silage is fermented

13 (Masters et al. 2001). Seeds are large and produced on upright stems, making harvesting with

14 conventional cereal headers feasible. Preliminary studies also indicate it resists attacks by redlegged earth mites at the cotyledon stage (PGH Nichols, unpublished data). A technical limitation, however, is the lack of a Rhizobium strain able to nodulate regenerating plants under saline conditions (Charman et al. 2006). Although M. siculus nodulated effectively in

18 the year of establishment, very few plants nodulated in subsequent years. Had a suitable strain

19 been present, herbage production in the second and third years at these sites may have been substantially higher. A greater understanding of the soil texture and $\mathrm{pH}$ requirements of the species is also required before its full potential can be identified.

Evans and Kearney (2003) showed that Melilotus albus can be highly productive when grown on raised beds of saline alkaline soils in western Victoria. However, it failed to persist

24 beyond the first year at Keith. M. albus was not evaluated in Western Australia, due to concerns about its high coumarin levels and possible weediness, but it is unlikely to be 
adapted to many saline environments in that State, due to its late flowering, lack of waterlogging tolerance and preference for alkaline soils.

Of the other annual Melilotus species, M. infestus and M. indicus were well adapted at

4 Keith and appear to have tolerance to both salinity and waterlogging. The results for $M$. indicus are consistent with those of Maranon et al. (1989). However, both species tend to have high coumarin levels, precluding their use as agricultural plants unless low-coumarin genotypes can be found. No other annual Melilotus species appear to have merit as pasture plants for saline land, although Boschma et al. (2007, this issue) found that M. sulcatus had

9 similar herbage production to Scimitar burr medic at 2 mildly saline sites in northern New 10 South Wales.

Naturalised species. Trifolium tomentosum was among the most persistent species at

12 Tammin and its herbage production was not significantly lower than Scimitar burr medic in

13 either of the first 2 years. Its adaptation was not surprising, as the species is widely distributed

14 in valleys of the Western Australian wheatbelt (Gibberd and Cocks 1997). It was noticeable that many of the poorer plots at Tammin became invaded by local T. tomentosum strains and that these strains appeared to be more productive and persistent than the sown composites.

17 This gives rise to the potential for selecting productive T. tomentosum genotypes for low

18 rainfall saline environments. Trifolium ornithopodioides was also persistent at Keith and is

19 widespread on waterlogged saline sites in the surrounding district (AD Craig, personal observations). However, its very low productivity in these experiments and those of Boschma et al. (2007, this issue) makes it unattractive for cultivar development.

When should salinity levels be measured?

24 These experiments and those of Smith and Stoneman (1970) showed seasonal variability in mean soil surface salinity levels within sites, with maximum levels occurring in summer and 
autumn. The question arises as to the optimum time to measure salinity levels, in order to determine the most suitable annual legume options for southern Australia. The ability of regenerating seedlings, more so than newly sown plants, to germinate and establish at these sites appears to be a critical factor for their long-term persistence. This suggests that salinity measurements in the winter-dominant rainfall areas of southern Australia should ideally be made in early autumn (prior to opening seasonal rains) to reflect the highest levels regenerating pasture seeds could be subjected to at germination. Measurements in summer will be similar and could also be used. However, this proposal is based on a limited number of

9 observations and soil types and further research is required to validate it. It also needs to be recognised that critical salinity levels for germination are most probably within $1 \mathrm{~cm}$ of the surface, whereas measurements are usually made of the top $10 \mathrm{~cm}$.

Species for different saline environments.

14 These experiments allow the following broad annual legume species recommendations to be made for the different salinity categories of Rogers et al. (2005). Recommendations of cultivars within species can then be based on matching flowering time to mean growing season length for particular target localities. Mixtures of species and cultivars should be employed to take account of the high spatial variability for salinity and waterlogging.

19 (i) For well-drained sites with only transient waterlogging, burr medics are the most suited. Barrel medics can be mixed with them on alkaline clays. The upper $\mathrm{EC}_{\mathrm{e}}$ levels for survival of these species are not well defined, although Scimitar burr medic persisted at Keith on soil with a 0-10 cm summer $\mathrm{EC}_{\mathrm{e}}$ level of $36 \mathrm{dS} / \mathrm{m}$.

(ii) On low to moderately saline $\left(0-10 \mathrm{~cm}\right.$ summer $\mathrm{EC}_{\mathrm{e}}$ levels $\left.<8 \mathrm{dS} / \mathrm{m}\right)$, poorly drained sites subject to prolonged waterlogging, balansa and Persian clovers can be highly productive, particularly at lower $\mathrm{EC}_{\mathrm{e}}$ levels. 
1 (iii) On highly saline $\left(0-10 \mathrm{~cm}\right.$ summer $\mathrm{EC}_{\mathrm{e}}$ levels $\left.>8 \mathrm{dS} / \mathrm{m}\right)$, poorly drained sites, subject to prolonged waterlogging there are currently no well-adapted commercial annual legume species. However, Melilotus siculus has the potential to fulfil this role.

Further research

6 These experiments have highlighted plant selection opportunities to improve the productivity of saline land. A range of $M$. polymorpha germplasm is being examined to identify genotypes with greater salinity and waterlogging tolerance than current cultivars. Evaluation of 15

9 Melilotus siculus genotypes has commenced in Western Australia and South Australia

10 (Nichols et al. 2007a) with the view of developing a new pasture species for saline

11 waterlogged soils. Critical to further development of M. siculus are a Rhizobium strain

12 capable of persisting and nodulating the plant under saline conditions (Charman et al. 2006)

13 and a greater understanding of its soil $\mathrm{pH}$ and texture requirements. Further work is required

14 to better understand the relationships between germination response, the timing and intensity

15 of rainfall events and salinity levels in the topsoil for a range of legumes. A greater

16 understanding of salinity tolerance and salt avoidance mechanisms is also required. Such

17 information would better define annual pasture legume ideotypes for saline land. New genotype evaluation methods need to be considered for plants adapted to saline

19 landscapes, as high variability for salinity and waterlogging at such sites limits the use of traditional genotype evaluation plots. Treatment replication needs to be high and tolerance thresholds to both factors are difficult to define. One option is use of transects along salinity and waterlogging gradients and correlating plant growth and persistence with changes in the levels of both factors. Use of such transects has proved useful for preliminary species comparisons (Nichols unpublished data) and is an effective extension tool for creating farmer awareness of different plant options. 


\section{Acknowledgements}

3 We would like to thank Tony York, Ian Peirce, Andrew Toovey, Dennis and Heather Sanders

4 and Lewis Watson and their families for their support and use of land to conduct the research.

5 The able technical assistance of Wayne Dempsey, David Cornwall and Graeme Phyland is

6 gratefully acknowledged. Rhizobia were supplied by Nigel Charman and Ross Ballard (South

7 Australian Research and Development Institute). The helpful comments of Dr Ed Barrett-

8 Lennard and another anonymous referee improved the manuscript. Funding was provided by

9 the Grains Research and Development Corporation and Land, Water and Wool, (a joint

10 initiative of Land and Water Australia and Australian Wool Innovation), through the

11 Sustainable Grazing on Saline Lands sub-program (which included co-investment from Meat

12 and Livestock Australia).

13

\section{References}

\section{Barrett-Lennard EG (2003a) The interaction between waterlogging and salinity in higher} plants: causes, consequences and implications. Plant and Soil 253, 35-54.

Barrett-Lennard EG (2003b) Saltland Pastures in Australia - A Practical Guide ( $2^{\text {nd }}$ edition). Department of Agriculture Western Australia, South Perth, Australia.

Boschma SP, Lodge GM, Harden S (2007) Performance and persistence of pasture legumes and grasses in saline and/or waterlogged soils in northern New South Wales. Australian Journal of Experimental Agriculture 47, this issue

Charman N, Ballard R, Craig A (2006) Melilotus siculus (syn messanensis) is constrained by a lack of suitable rhizobia. In 'Ground-breaking stuff. Proceedings of the 13th agronomy conference'. (Eds NC Turner, T Acuna, RC Johnson), (Agronomy Society of Australia: Perth) Available at http://www.regional.org.au/au/asa/2006/poster/environment/4575_charmann.htm [Verified 2 November 2007] 
Craig AD (1999) Pasture legumes for saline environments. In 'Proceedings of the $6^{\text {th }}$ workshop on Productive Use and Rehabilitation of Saline Land (PURSL)', Naracoorte, South Australia.

Craig AD, Sandral GA, Dear BS, Latta RA, Evans PM, Hill NL (2000) Register of Australian herbage plant cultivars. B. Legumes.1.Clover-(k). Trifolium michelianum Savi (balansa clover) cv. Frontier. Australian Journal of Experimental Agriculture 40, 1201-1202.

Dear BS and Ewing MA (2007) The search for new pasture plants to achieve more sustainable production systems in southern Australia Australian Journal of Experimental Agriculture 47, this issue

Dear BS, Sandral GA, Peoples MB, Wilson BCD, Taylor JN, Rodham CA (2003) Growth, seed set and nitrogen fixation of 28 annual legume species on 3 Vertisol soils in southern New South Wales. Australian Journal of Experimental Agriculture 43, 11011115.

Dolling PJ, Moody P, Noble A, Helyar KR, Hughes B, Reuter D, Sparrow L (2001) 'National Land and Water Resources Audit.' National Land and Water Resources Audit, Commonwealth of Australia.

Ehrman T, Cocks PS (1996) Reproductive patterns in annual legume species on an aridity gradient. Vegetation 122, 47-59.

Evans PM, Cameron (1998) Performance of pasture legumes on three contrasting soil types in western Victoria. In 'Proceedings of the 9th Australian Agronomy Conference'. (Eds DL Michalk, JE Pratley) pp. 174-177. (Australian Society of Agronomy: Wagga Wagga, NSW) Available at http://www.regional.org.au/au/asa/1998/1/052evans.htm\#P1_82 [Verified 2 November 2007]

Evans PM, Kearney GA (2003) Melilotus albus (Medik.) is productive and persistent on saline soils of neutral to alkaline reaction in the high rainfall zone of south-west Victoria. Australian Journal of Experimental Agriculture 43, 349-355.

Evans PM, Snowball RS (1993) Balansa and Persian clover lines outproduce registered cultivars, and subterranean clover and annual medics, in a $400 \mathrm{~mm}$ annual rainfall zone in Western Australia. In 'Proceedings of the 7th Australian Agronomy Conference' (Eds GK McDonald, WD Bellotti). pp. 53-56. (Australian Society of Agronomy: Adelaide)

Garthwaite AJ, von Bothmer R, Colmer TD (2003) Diversity in root aeration traits associated with waterlogging tolerance in the genus Hordeum. Functional Plant Biology 30, 875889. 
Gibberd MR, Cocks PS (1997) Effect of waterlogging and soil pH on the micro-distribution of naturalised annual legumes. Australian Journal of Agricultural Research 48, 23-229.

Gibberd MR, Gray JD, Cocks PS, Colmer TD (2001) Waterlogging tolerance among a diverse range of Trifolium accessions is related to root porosity, lateral root formation and “aerotropic rooting'. Annals of Botany 88, 579-589.

Hall EJ, Evans PM (2001) The performance of a range of annual pasture legumes on acid saline soils in Tasmania. In 'Proceedings of the 10th Australian Agronomy Conference' (Australian Society of Agronomy: Hobart, Tasmania)

Jeanes JA (1996). Fabaceae, Melilotus. Flora of Victoria Volume 3, Dicotyledons: Winteraceae to Myrtacea. (Eds NG Walsh, TJ Entwhistle) pp 719-721 (Inkata Press: Melbourne)

Loi A, Howieson JG, Nutt BJ, Carr SJ (2005) A second generation of annual pasture legumes and their potential for inclusion in Mediterranean-type farming systems. Australian Journal of Experimental Agriculture 45, 289-299.

Maranon T, Garcia LV, Troncoso A (1989) Salinity and germination of annual Melilotus from the Guadalquiver delta (SW Spain). Plant and Soil 119, 223-228.

Masters DG, Norman HC, Dynes RA (2001) Opportunities and limitations for animal production from saline land. Asian-Australian Journal of Animal Science 14, 119-211.

McDonald RC, Isbell RF, Speight JG, Walker J, Hopkins MS (1990) Australian soil and land survey field handbook ( $2^{\text {nd }}$ edition). (Inkata Press: Melbourne)

Nichols PGH, Loi A, Nutt BJ, Evans PM, Craig AD, Pengelly BC, Dear BS, Lloyd DL, Revell CK, Nair RM, Ewing MA, Howieson JG, Auricht GA, Howie JH, Sandral GA, Carr SJ, de Koning CT, Hackney BF, Crocker GJ, Snowball R, Hughes SJ, Hall EJ, Foster KJ, Skinner PW, Barbetti MJ, You MP (2007a) New annual and short-lived perennial pasture legumes for Australian agriculture - 15 years of revolution. Field Crops Research 104, 10-23.

Nichols PGH, Rogers ME, Craig AD, Albertsen TO, Miller S, McClements DR, Hughes SJ, D’Antuono MF, Dear BS (2007b) Production and persistence of temperate perennial grasses and legumes at five saline sites in southern Australia. Australian Journal of Experimental Agriculture 47, this issue

Norman HC, Cocks PS, Smith FP, Nutt BJ (1998) Reproductive strategies in Mediterranean annual clovers: germination and hardseededness. Australian Journal of Agricultural Research 49, 973-982. 
Norman HC, Smith FP, Nichols PGH, Si P, Galwey NW (2006) Variation in seed softening patterns and impact of seed production environment on hardseededness in early maturing genotypes of subterranean clover. Australian Journal of Agricultural Research 57, 65-74.

O'Connell M, Young J, Kingwell R (2005) The economic value of saltland pastures in a mixed enterprise farming system in a heterogeneous landscape experiencing a mediterranean climate. Agricultural Systems 89, 371-389.

Paczkowska G, Chapman AR (2000) The Western Australia Flora: a descriptive catalogue. (The Wildflower Society of Western Australia, Western Australian Herbarium, Botanic Gardens Park Authority: Perth) 652 pages

Rogers AL, Bailey ET (1963) Salt tolerance trials with forage plants in south-western Australia. Australian Journal of Experimental Agriculture and Animal Husbandry $\mathbf{3}$, 125-130.

Rogers ME, Craig AD, Munns R, Colmer TD, Nichols PGH, Malcolm CV, Brown AJ, Semple WS, Evans PM, Cowley K, Hughes SJ, Snowball RS, Bennett SJ, Sweeney GC, Dear BS, Ewing ME (2005) The development of fodder plants for the salt-affected areas of southern and eastern Australia: an overview. Australian Journal of Experimental Agriculture 45, 301-329.

Rogers M, Colmer T, Frost K, Henry D, Cornwall D, Hulm E, Hughes S, Craig A (2006) Improving forage legume options for saline environments - Melilotus species. In 'Ground-breaking stuff. Proceedings of the 13th agronomy conference'. (Eds NC Turner, T Acuna, RC Johnson), (Agronomy Society of Australia: Perth) Available at http://www.regional.org.au/au/asa/2006/concurrent/environment/4548_rogersm.htm [Verified 2 November 2007]

Rogers ME, Noble CL (1991) The effect of $\mathrm{NaCl}$ on the establishment and growth of balansa clover (Trifolium michelianum Savi var. balansae Boiss.). Australian Journal of Agricultural Research 42, 847-857.

Rogers ME, Noble CL, Pederick RJ (1997) Identifying suitable temperate forage legume species for saline areas. Australian Journal of Experimental Agriculture 37, 639-645.

Rogers ME, West DW (1993) The effects of root zone salinity and hypoxia on shoot and root growth in Trifolium species. Annals of Botany 72, 503-509.

Russell JS (1976) Comparative salt tolerance of some tropical and temperate legumes and grasses. Australian Journal of Experimental Agriculture and Animal Husbandry 16, 103-109. 
Slavich PG, Peterson GH (1993) Estimating the electrical conductivity of saturated paste extracts from 1:5 soil: water suspensions and texture. Australian Journal of Soil Research 31, 73-81.

Smith ST, Stoneman TC (1970) Salt movement in bare saline soils. Technical Bulletin 4. Department of Agriculture Western Australia, South Perth, Australia.

Stevenson GA (1969) An agronomic and taxonomic review of the genus Melilotus Mill. Canadian Journal of Plant Science 49, 1-20.

Stone L (2007) Minimising environmental weed risk in new perennial-based land-use systems. Australian Journal of Experimental Agriculture 47, this issue

Taylor GB (1996) Incidence and measurement of autumn seed softening within Medicago polymorpha L. Australian Journal of Agricultural Research 47, 575-586.

Taylor GB, Maller RA, Rossiter RC (1991) A model describing the influence of hardseededness on the persistence of an annual forage legume, in a ley farming system, in a mediterranean-type environment. Agriculture, Ecosystems and Environment 37, 275-301.

16 West DW, Taylor JA (1981) Germination and growth of cultivars of Trifolium subterraneum 
1 Table 1. Experimental site locations, mean annual rainfall (data from Bureau of

2 Meteorology) and mean soil properties (0-10 $\mathrm{cm}$ depth) of bulked samples.

\begin{tabular}{cccccccc}
\hline \multicolumn{1}{c}{ Site } & Location & $\begin{array}{c}\text { Mean annual } \\
\text { rainfall }(\mathrm{mm})\end{array}$ & $\begin{array}{c}\mathrm{pH} \\
\left(\mathrm{CaCl}_{2}\right)\end{array}$ & $\begin{array}{c}\mathrm{EC}_{\mathrm{e}}(\mathrm{dS} / \mathrm{m})^{\mathrm{A}} \\
\text { Winter }\end{array}$ & $\begin{array}{c}\text { Drainage } \\
\text { Summer }\end{array}$ & $\begin{array}{c}\text { Soil texture } \\
\text { rating }^{\mathrm{B}}\end{array}$ & rating $^{\mathrm{C}}$ \\
\hline Tammin & $31.60^{\circ} \mathrm{S}, 117.45^{\circ} \mathrm{E}$ & 330 & 6.5 & 2.4 & 10.9 & 6 & 6 \\
Duranillin & $33.57^{\circ} \mathrm{S}, 116.77^{\circ} \mathrm{E}$ & 530 & 5.5 & 5.0 & 30.8 & 2 & 2 \\
Cranbrook & $34.15^{\circ} \mathrm{S}, 117.18^{\circ} \mathrm{E}$ & 530 & 5.6 & 3.2 & 8.0 & 4 & 4 \\
Girgarre & $36.35^{\circ} \mathrm{S}, 144.97^{\circ} \mathrm{E}$ & 450 & 5.5 & 1.9 & 6.9 & 4 & 9 \\
Keith & $36.15^{\circ} \mathrm{S}, 140.10^{\circ} \mathrm{E}$ & 465 & 6.7 & 0.8 & 36.2 & 2 & 1
\end{tabular}

$3{ }^{\mathrm{A}}$ Mean salinity values at each site in winter (minimum) and summer (maximum)

$4 \quad{ }^{\text {B }}$ Rating scale (1-6) from McDonald et al. (1990), where 2 = poorly drained (seasonally inundated), $4=$

5 moderately drained (potential for shallow waterlogging), $6=$ rapidly drained (no chance of inundation

6 or waterlogging)

$7 \quad{ }^{C}$ Rating scale (1-13) based on McDonald et al. (1990), where 1 = sand, $3=$ clayey sand, $5=10 a m, 7=$

8 clay loam, 9 = light clay, $11=$ medium clay, 13 = heavy clay 
1 Table 2. Species and genotypes sown at the 5 experimental sites. Entries consisted of either single genotypes or composites of 2 - 4

2 genotypes mixed in equal proportions.

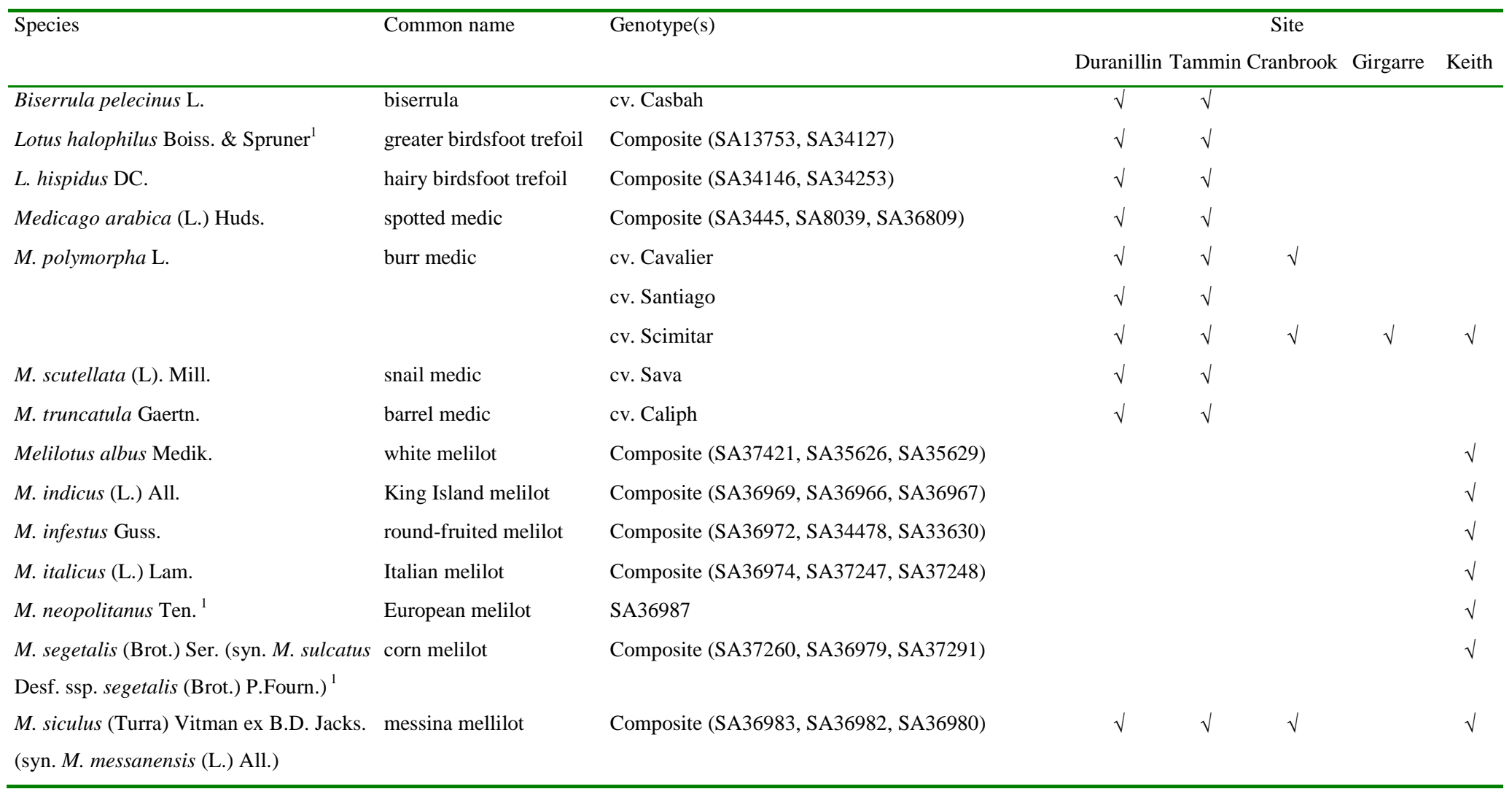

Formatted: Right: $0.63 \mathrm{~cm}$ 


\begin{tabular}{|c|c|c|c|c|c|c|c|}
\hline \multirow{2}{*}{$\begin{array}{l}\text { M. speciosus Durieu } \\
\text { M. sulcatus Desf. (syn. M. sulcatus Desf. } \\
\text { ssp. brachystachys (Brot.) P.Fourn.) }{ }^{1}\end{array}$} & \multirow[b]{2}{*}{ furrowed melilot } & \multicolumn{5}{|l|}{ Composite (SA36985, SA36986) } & \multirow{2}{*}{$\begin{array}{l}\sqrt{ } \\
\sqrt{ }\end{array}$} \\
\hline & & Composite (SA34477, SA34482) & $\sqrt{ }$ & $\sqrt{ }$ & $\sqrt{ }$ & $\sqrt{ }$ & \\
\hline Ornithopus pinnatus Mill. & slender seradella & cv. Jebala & $\sqrt{ }$ & $\sqrt{ }$ & & & \\
\hline O. sativus Brot. & French serradella & cv. Margurita & $\sqrt{ }$ & $\sqrt{ }$ & & & \\
\hline \multirow[t]{2}{*}{ Trifolium alexandrinum $\mathrm{L}$. } & berseem clover & cv. Big Bee & $\sqrt{ }$ & $\sqrt{ }$ & & & \\
\hline & & Composite (SA33621, SA33622) & & & & & $\sqrt{ }$ \\
\hline T. clusii Godr. \& Gren. & annual strawberry clover & Composite (SA33623, SA33625, SA33624) & $\sqrt{ }$ & $\sqrt{ }$ & & & \\
\hline T. dasyurum C. Presl. & eastern star clover & cv. AGWEST Sothis & & & $\sqrt{ }$ & & \\
\hline T. glanduliferum Boiss. & gland clover & cv. Prima & $\sqrt{ }$ & $\sqrt{ }$ & & & \\
\hline T. incarnatum $\mathrm{L}$. & crimson clover & cv. Caprera & $\sqrt{ }$ & $\sqrt{ }$ & & & \\
\hline \multirow[t]{2}{*}{ T. isthmocarpum Brot. } & Moroccan clover & Early flowering selections from 30 genotypes & $\sqrt{ }$ & $\sqrt{ }$ & $\sqrt{ }$ & & $\sqrt{ }$ \\
\hline & & H14129 & & & & $\sqrt{ }$ & \\
\hline \multirow[t]{3}{*}{ T. michelianum Savi } & balansa clover & cv. Bolta & $\sqrt{ }$ & $\sqrt{ }$ & $\sqrt{ }$ & $\sqrt{ }$ & $\sqrt{ }$ \\
\hline & & cv. Frontier & $\sqrt{ }$ & $\sqrt{ }$ & $\sqrt{ }$ & $\sqrt{ }$ & $\sqrt{ }$ \\
\hline & & cv. Paradana & $\sqrt{ }$ & $\sqrt{ }$ & & & \\
\hline T. ornithopodioides $\mathrm{L}$. & birdsfoot clover & Composite (SA4544, SA33629, SA19870, SA36328) & $\sqrt{ }$ & $\sqrt{ }$ & $\sqrt{ }$ & $\sqrt{ }$ & $\sqrt{ }$ \\
\hline T. purpureum Loisel. & purple clover & cv. Paratta & $\sqrt{ }$ & $\sqrt{ }$ & & & $\sqrt{ }$ \\
\hline \multirow[t]{3}{*}{ T. resupinatum $\mathrm{L}$. } & Persian clover & cv. Nitro Plus & $\sqrt{ }$ & $\sqrt{ }$ & $\sqrt{ }$ & $\sqrt{ }$ & $\sqrt{ }$ \\
\hline & & cv. Persian Prolific & $\sqrt{ }$ & $\sqrt{ }$ & $\sqrt{ }$ & & $\sqrt{ }$ \\
\hline & & SA33804 & $\sqrt{ }$ & $\sqrt{ }$ & & & \\
\hline T. spumosum $\mathrm{L}$. & bladder clover & Composite (SA363, SA35625, SA16698, SA35708) & $\sqrt{ }$ & $\sqrt{ }$ & & & \\
\hline
\end{tabular}

Formatted: Right: $0.63 \mathrm{~cm}$ 
T. squamosum $\mathrm{L}$.

T. subterraneum $\mathrm{L}$. var. subterraneum

(Katzn. \& Morley) Zohary

T. subterraneum L. var. yanninicum

(Katzn. \& Morley) Zohary

T. tomentosum L.

Trigonella balansae Boiss. \& Reut.

Total number of entries

${ }^{\mathrm{T}}$ Currently prohibi

$\begin{array}{lllllll}\text { sea clover } & \text { Composite (SA368, SA370) } & \sqrt{ } & \sqrt{ } & & \sqrt{ } \\ \text { subterranean clover } & \text { cv. Dalkeith } & \sqrt{ } & \sqrt{ } & & \\ \text { subterranean clover } & \text { cv. Trikkala } & & & & & \\ & & \sqrt{ } & \sqrt{ } & \sqrt{ } & \sqrt{ } & \sqrt{ } \\ \text { woolly clover } & \text { Composite (SA35654, SA8462, SA14425, SA22815) } & \sqrt{ } & \sqrt{ } & \sqrt{ } & \sqrt{ } & \sqrt{ } \\ & \text { SA5045 } & \sqrt{ } & \sqrt{ } & \sqrt{ } & \sqrt{ } & \sqrt{ } \\ & & 32 & 32 & 14 & 11 & 21\end{array}$


1 Table 3. Annual and May-November rainfall $(\mathrm{mm})$ recorded at each site during

2 the experimental period. Data from the Bureau of Meteorology.

\begin{tabular}{lccccc}
\hline Site & Tammin & Duranillin & Girgarre & Keith & Cranbrook \\
\hline 2003 & & & & & \\
Total & 386 & 478 & 360 & 449 & \\
May-Nov & 252 & 379 & 248 & 339 & \\
2004 & & & & & \\
Total & 248 & 370 & 421 & 411 & 375 \\
May-Nov & 214 & 338 & 292 & 339 & 332 \\
2005 & & & & & \\
Total & 293 & 530 & 399 & 413 & 670 \\
May-Nov & 250 & 404 & 302 & 311 & 451 \\
2006 & & & & \\
Total & & & & & \\
May-Nov & & & & & \\
\hline
\end{tabular}

3 
1 Table 4. Annual legume establishment densities ( $\log _{10}$ transformed data) at 5

2 experimental sites $(P<0.001)$. Raw means $\left(\right.$ plants $\left./ \mathbf{m}^{2}\right)$ are shown in parentheses.

\begin{tabular}{|c|c|c|c|c|c|c|c|c|c|}
\hline \multirow{3}{*}{$\begin{array}{l}\text { Species } \\
\text { Biserrula pelecinus cv. Casbah }\end{array}$} & \multicolumn{8}{|c|}{ Site } & \\
\hline & \multicolumn{2}{|c|}{ Tammin } & Duranillin & \multicolumn{2}{|c|}{ Cranbrook } & \multicolumn{2}{|c|}{ Girgarre } & Keith & ith \\
\hline & 1.31 & $(21)$ & $0.00 \quad(0)$ & & & & & & \\
\hline Lotus halophilus & 1.30 & $(29)$ & $0.11 \quad(0)$ & & & & & & \\
\hline L. hispidus & 2.06 & (139) & $1.26(20)$ & & & & & & \\
\hline Medicago arabica & 1.36 & $(34)$ & $0.28 \quad(2)$ & & & & & & \\
\hline M. polymorpha cv. Cavalier & 1.64 & $(46)$ & $0.90 \quad(12)$ & 2.09 & $(138)$ & & & & \\
\hline M. polymorpha cv. Santiago & 1.59 & (39) & $0.47 \quad(5)$ & & & & & & \\
\hline M. polymorpha cv. Scimitar & 1.61 & $(45)$ & 0.80 & 2.60 & $(430)$ & 1.68 & $(52)$ & 2.66 & $(462)$ \\
\hline M. scutellata cv. Sava & 0.87 & (8) & $0.06 \quad(0)$ & & & & & & \\
\hline M. truncatula cv. Caliph & 1.37 & (29) & $0.38 \quad(5)$ & & & & & & \\
\hline Melilotus albus & & & & & & & & 2.64 & $(438)$ \\
\hline M. indicus & & & & & & & & 2.88 & $(766)$ \\
\hline M. infestus & & & & & & & & 2.65 & $(470)$ \\
\hline M. italicus & & & & & & & & 2.31 & (212) \\
\hline M. neopolitanus & & & & & & & & 2.54 & $(348)$ \\
\hline M. segetalis & & & & & & & & 2.49 & $(314)$ \\
\hline M. siculus & 1.21 & $(17)$ & $1.52(37)$ & 1.87 & (83) & & & 2.30 & $(202)$ \\
\hline M. speciosus & & & & & & & & 2.23 & $(170)$ \\
\hline M. sulcatus & 1.34 & $(29)$ & $0.28 \quad(1)$ & 1.87 & $(90)$ & 1.29 & $(23)$ & 2.45 & $(288)$ \\
\hline Ornithopus pinnatus cv. Jebala & 1.88 & (114) & $0.00 \quad(0)$ & & & & & & \\
\hline O. sativus $\mathrm{cv}$. Margurita & 0.83 & $(9)$ & $0.10 \quad(0)$ & & & & & & \\
\hline Trifolium alexandrinum & 0.65 & (6) & $0.51 \quad(8)$ & & & & & 2.63 & $(436)$ \\
\hline T. clusii & 1.82 & $(112)$ & $0.00 \quad(0)$ & & & & & & \\
\hline T. dasyurum cv. AGWEST Sothis & & & & 1.88 & $(85)$ & & & & \\
\hline T. glanduliferum cv. Prima & 1.43 & $(55)$ & $0.00 \quad(0)$ & & & & & & \\
\hline T. incarnatum cv. Caprera & 0.14 & $(0)$ & $0.18 \quad(1)$ & & & & & & \\
\hline T. isthmocarpum & 1.73 & (83) & $0.60 \quad(5)$ & 1.97 & (98) & 1.46 & $(37)$ & 3.08 & (1202) \\
\hline T. michelianum cv. Bolta & 1.84 & $(81)$ & 0.51 & 2.57 & $(383)$ & 1.66 & $(64)$ & 3.04 & (1118) \\
\hline T. michelianum cv. Frontier & 1.55 & (44) & $0.69 \quad(4)$ & 2.79 & $(623)$ & 1.66 & $(63)$ & 2.94 & (878) \\
\hline T. michelianum cv. Paradana & 2.08 & $(141)$ & 1.53 & & & & & & \\
\hline T. ornithopodioides & 2.16 & $(162)$ & $0.53 \quad(5)$ & 2.53 & $(420)$ & 1.48 & $(44)$ & 3.12 & $(1332)$ \\
\hline T. purpureum cv. Paratta & 0.90 & $(10)$ & $0.55 \quad(5)$ & & & & & 2.86 & (722) \\
\hline T. resupinatum cv. Nitro Plus & 0.86 & $(11)$ & $0.00 \quad(0)$ & 2.50 & $(360)$ & 0.45 & (5) & 2.58 & $(382)$ \\
\hline & & & & & & & & & Formatted: Right: $0.63 \mathrm{~cm}$ \\
\hline
\end{tabular}




\begin{tabular}{|c|c|c|c|c|c|c|c|c|c|c|}
\hline T. resupinatum cv. Persian Prolific & 1.61 & (39) & 0.74 & $(12)$ & 2.65 & $(459)$ & & & 2.85 & $(716)$ \\
\hline T. resupinatum SA33804 & 1.82 & $(78)$ & 0.18 & (1) & & & & & & \\
\hline T. spumosum & 1.65 & $(52)$ & 0.26 & (1) & & & & & & \\
\hline T. squamosum & 0.87 & (9) & 0.00 & (0) & & & 1.17 & (17) & & \\
\hline T. subterraneum cv. Dalkeith & 0.24 & (1) & 0.00 & (0) & & & & & & \\
\hline T. subterraneum cv. Trikkala & 0.60 & (6) & 0.20 & (1) & 1.85 & (73) & 1.10 & (14) & 2.15 & $(142)$ \\
\hline T. tomentosum & 1.80 & $(83)$ & 0.00 & (0) & 2.67 & $(503)$ & 0.73 & (14) & 3.12 & $(1308)$ \\
\hline Trigonella balansae SA5045 & 0.95 & $(16)$ & 0.65 & $(13)$ & 2.10 & $(138)$ & 1.41 & $(43)$ & 2.89 & (778) \\
\hline Site mean & & $(48)$ & & (6) & & (277) & & (34) & & (584) \\
\hline 1.s.d. $(P=0.05)$ & 0.452 & & 0.483 & & 0.288 & & 0.527 & & 0.076 & \\
\hline
\end{tabular}


1 Table 5. Rhizobial nodulation and plant health ratings following 7 weeks of

2 inundation at Keith in the year of sowing $(P<0.001)$.

\begin{tabular}{|c|c|c|}
\hline Species & Nodulation rating $(0-3)^{A}$ & Plant health rating $(0-5)^{\mathrm{B}}$ \\
\hline Medicago polymorpha cv. Scimitar & 3.0 & 2.9 \\
\hline Melilotus albus & 2.6 & 2.1 \\
\hline M. indicus & 3.0 & 3.2 \\
\hline M. infestus & 2.9 & 2.3 \\
\hline M. italicus & 2.2 & 1.0 \\
\hline M. neopolitanus & 1.6 & 0.6 \\
\hline M. segetalis & 3.0 & 3.3 \\
\hline M. siculus & $3.0^{\mathrm{C}}$ & 3.7 \\
\hline M. speciosus & 0.0 & 1.1 \\
\hline M. sulcatus & 2.9 & 0.9 \\
\hline Trifolium alexandrinum & 1.2 & 1.9 \\
\hline T. isthmocarpum & 3.0 & 4.0 \\
\hline T. michelianum cv. Bolta & 3.0 & 3.9 \\
\hline T. michelianum cv. Frontier & 3.0 & 3.4 \\
\hline T. ornithopodioides & 3.0 & 3.8 \\
\hline T. purpureum cv. Paratta & 3.0 & 3.8 \\
\hline T. resupinatum $\mathrm{cv}$. Nitro Plus & 3.0 & 3.0 \\
\hline T. resupinatum cv. Persian Prolific & 3.0 & 3.3 \\
\hline T. subterraneum cv. Trikkala & 2.9 & 2.4 \\
\hline T. tomentosum & 2.9 & 3.9 \\
\hline Trigonella balansae SA5045 & 2.9 & 1.4 \\
\hline Site mean & 2.6 & 2.7 \\
\hline 1.s.d. $(P=0.05)$ & 0.41 & 0.44 \\
\hline
\end{tabular}

$3{ }^{\mathrm{A}} 0=$ no nodules, $1=$ small white nodules only, $2=$ less than 5 pink nodules and $3=$ at least 5

4 pink nodules.

$5 \quad{ }^{\mathrm{B}} 0=$ all plants dead, $5=$ all plants green and healthy.

$6{ }^{C}$ Nodulation failure tended to occur in regenerating pastures (years 2 and 3 ). 
1 Table 6. First year spring herbage production ( $\log _{10}$ transformed data) at 5

2 experimental sites $(P<0.001)$. Raw means $(\mathrm{kg} / \mathrm{ha})$ are shown in parentheses.

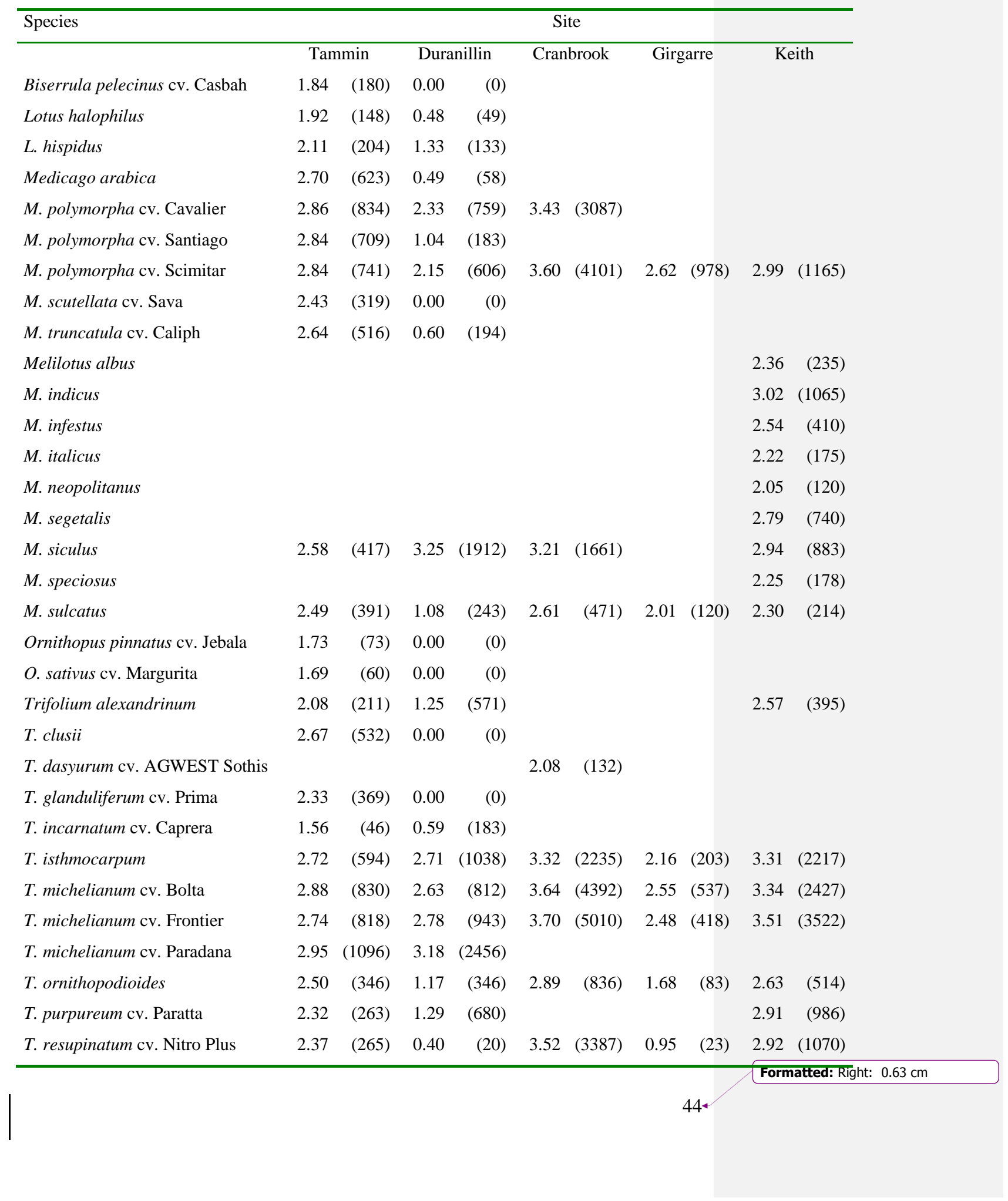




\begin{tabular}{lrrrrrrrrrrr}
\hline T. resupinatum cv. Persian Prolific & 2.90 & $(857)$ & 2.77 & $(1438)$ & 3.60 & $(3882)$ & & & 3.36 & $(2498)$ \\
T. resupinatum SA33804 & 2.80 & $(755)$ & 0.34 & $(10)$ & & & & & & & \\
T. spumosum & 2.75 & $(596)$ & 0.52 & $(78)$ & & & & & & \\
T. squamosum & 2.20 & $(176)$ & 0.00 & $(0)$ & & & & & \\
T. subterraneum cv. Dalkeith & 1.68 & $(97)$ & 0.00 & $(0)$ & & & & & & & \\
T. subterraneum cv. Trikkala & 2.18 & $(218)$ & 0.53 & $(94)$ & 2.60 & $(554)$ & 2.15 & $(230)$ & 2.31 & $(204)$ \\
T. tomentosum & 2.75 & $(644)$ & 0.00 & $(0)$ & 3.08 & $(1262)$ & 1.53 & $(53)$ & 2.77 & $(667)$ \\
Trigonella balansae SA5045 & 2.25 & $(342)$ & 0.70 & $(621)$ & 3.01 & $(1173)$ & 2.58 & $(484)$ & 2.43 & $(294)$ \\
Site mean & & $(446)$ & & $(420)$ & & $(2299)$ & & $(292)$ & & $(885)$ \\
1.s.d. $(P=0.05)$ & 0.404 & & 1.217 & & 0.262 & & 0.488 & & 0.157 & \\
\hline
\end{tabular}

1 
1 Table 7. Days to first flowering from sowing at Keith and the Tammin02 site and

2 seed production indices (square root transformed data) in year 1 at Tammin,

3 Cranbrook and Keith $(P<0.001)$. Raw means ( 0 - 25 ratings) are shown in

4 parentheses.

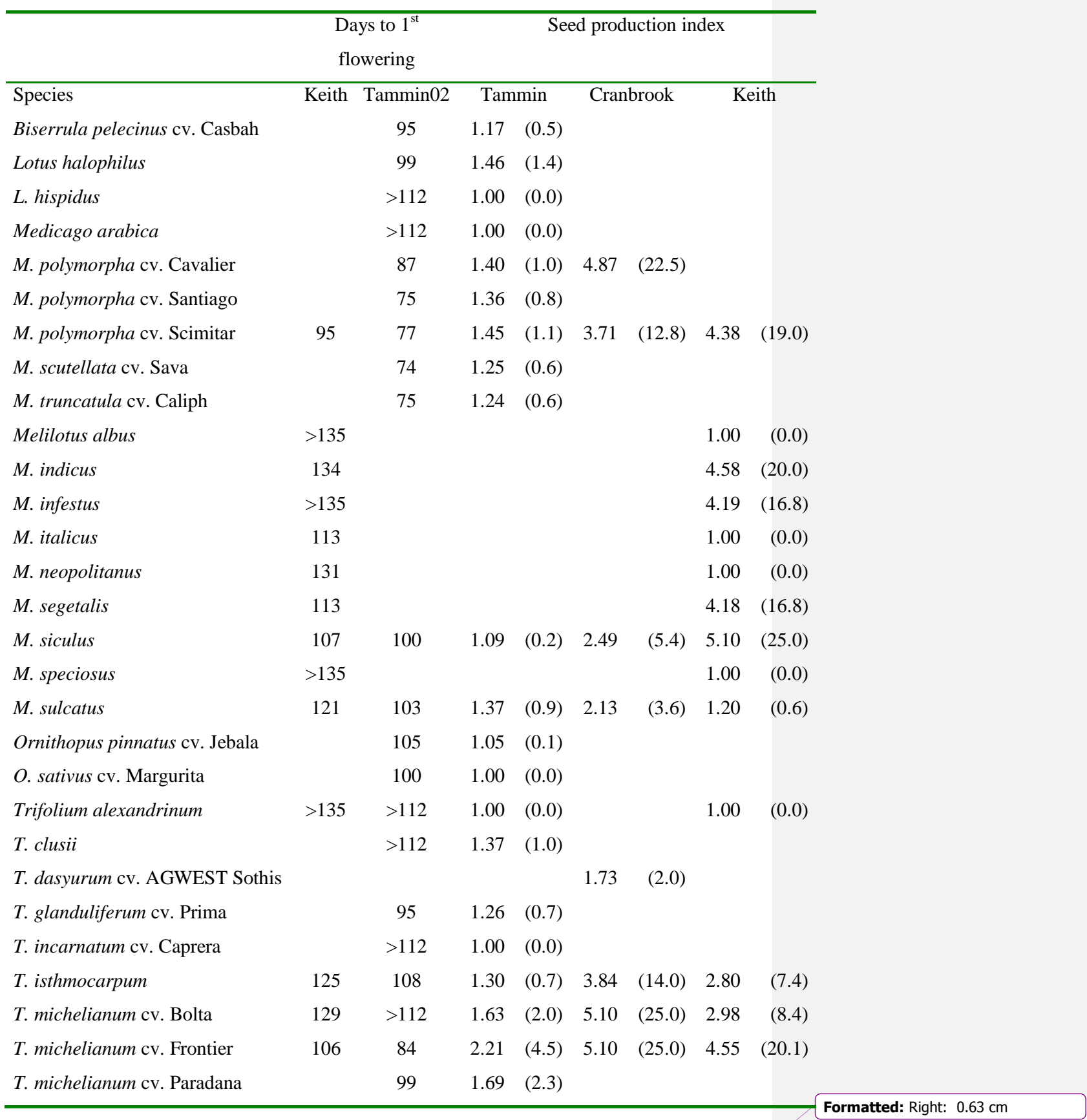




\begin{tabular}{lcccccccc}
\hline T. ornithopodioides & 121 & $>112$ & 1.00 & $(0.0)$ & 1.00 & $(0.0)$ & 4.02 & $(16.2)$ \\
T. purpureum cv. Paratta & 131 & $>112$ & 1.26 & $(0.6)$ & & & 1.00 & $(0.0)$ \\
T. resupinatum cv. Nitro Plus & 123 & 105 & 1.00 & $(0.0)$ & 3.92 & $(14.4)$ & 1.57 & $(1.8)$ \\
T. resupinatum cv. Persian Prolific & 122 & 98 & 1.43 & $(1.3)$ & 4.27 & $(17.0)$ & 3.90 & $(15.0)$ \\
T. resupinatum SA33804 & & 94 & 1.63 & $(1.9)$ & & & & \\
T. spumosum & & 110 & 2.27 & $(4.6)$ & & & & \\
T. squamosum & & $>112$ & 1.00 & $(0.0)$ & & & & \\
T. subterraneum cv. Dalkeith & & 98 & 1.00 & $(0.0)$ & & & & \\
T. subterraneum cv. Trikkala & 106 & 105 & 1.00 & $(0.0)$ & 2.13 & $(3.6)$ & 1.17 & $(0.4)$ \\
T. tomentosum & 95 & 98 & 2.32 & $(4.5)$ & 3.84 & $(14.0)$ & 4.47 & $(20.0)$ \\
Trigonella balansae SA5045 & 110 & 91 & 1.39 & $(1.0)$ & 2.82 & $(7.2)$ & 2.39 & $(6.2)$ \\
Site mean & & & & $(1.0)$ & & $(11.9)$ & & $(10.1)$ \\
1.s.d. $(P=0.05)$ & & & 0.416 & & 0.371 & & 0.622 & \\
\hline
\end{tabular}


1 Table 8. Second year autumn-winter annual legume regeneration densities $\left(\log _{10}\right.$

2 transformed data) at 5 experimental sites $(P<0.001)$. Raw means (plants $/ \mathrm{m}^{2}$ ) are

3 shown in parentheses.

\begin{tabular}{|c|c|c|c|c|c|c|c|c|c|c|c|}
\hline \multirow{3}{*}{$\begin{array}{l}\text { Species } \\
\text { Biserrula pelecinus cv. Casbah }\end{array}$} & \multicolumn{10}{|c|}{ Site } & \\
\hline & \multicolumn{2}{|c|}{ Tammin } & \multicolumn{2}{|c|}{ Duranillin } & \multicolumn{2}{|c|}{ Cranbrook } & \multicolumn{2}{|c|}{ Girgarre } & \multicolumn{2}{|c|}{ Keith } & \\
\hline & 0.16 & (1) & 0.00 & $(0)$ & & & & & & & \\
\hline Lotus halophilus & 0.36 & $(12)$ & 0.00 & $(0)$ & & & & & & & \\
\hline L. hispidus & 0.00 & $(0)$ & 0.10 & $(0)$ & & & & & & & \\
\hline Medicago arabica & 0.16 & (1) & 0.00 & $(0)$ & & & & & & & \\
\hline M. polymorpha cv. Cavalier & 2.79 & $(677)$ & 0.00 & $(0)$ & 1.67 & $(106)$ & & & & & \\
\hline M. polymorpha cv. Santiago & 2.97 & (997) & 0.10 & $(0)$ & & & & & & & \\
\hline M. polymorpha cv. Scimitar & 3.19 & (1623) & 0.01 & $(0)$ & 2.11 & $(142)$ & 1.14 & (14) & 2.34 & (223) & \\
\hline M. scutellata cv. Sava & 2.33 & (306) & 0.00 & $(0)$ & & & & & & & \\
\hline M. truncatula cv. Caliph & 2.51 & $(426)$ & 0.00 & $(0)$ & & & & & & & \\
\hline Melilotus albus & & & & & & & & & 0.00 & (0) & \\
\hline M. indicus & & & & & & & & & 2.23 & (204) & \\
\hline M. infestus & & & & & & & & & 2.22 & $(390)$ & \\
\hline M. italicus & & & & & & & & & 0.16 & (1) & \\
\hline M. neopolitanus & & & & & & & & & 0.00 & $(0)$ & \\
\hline M. segetalis & & & & & & & & & 1.70 & (54) & \\
\hline M. siculus & 0.00 & $(0)$ & 2.57 & $(388)$ & 2.43 & $(303)$ & & & 2.67 & $(513)$ & \\
\hline M. speciosus & & & & & & & & & 0.00 & $(0)$ & \\
\hline M. sulcatus & 0.47 & (6) & 0.00 & (0) & 0.77 & (8) & 0.00 & $(0)$ & 0.40 & (4) & \\
\hline Ornithopus pinnatus cv. Jebala & 0.27 & (4) & 0.00 & $(0)$ & & & & & & & \\
\hline O. sativus cv. Margurita & 0.00 & $(0)$ & 0.00 & $(0)$ & & & & & & & \\
\hline Trifolium alexandrinum & 0.38 & (3) & 0.00 & (0) & & & & & 0.00 & $(0)$ & \\
\hline T. clusii & 1.25 & $(176)$ & 0.00 & $(0)$ & & & & & & & \\
\hline T. dasyurum cv. AGWEST Sothis & & & & & 0.00 & $(0)$ & & & & & \\
\hline T. glanduliferum cv. Prima & 0.56 & (12) & 0.00 & $(0)$ & & & & & & & \\
\hline T. incarnatum cv. Caprera & 0.00 & $(0)$ & 0.01 & $(0)$ & & & & & & & \\
\hline T. isthmocarpum & 0.47 & (8) & 0.00 & $(0)$ & 1.93 & (99) & 0.17 & (1) & 1.11 & (28) & \\
\hline T. michelianum cv. Bolta & 1.09 & (87) & 0.06 & $(0)$ & 2.38 & $(252)$ & 0.00 & $(0)$ & 1.05 & (17) & \\
\hline T. michelianum cv. Frontier & 1.42 & (91) & 0.00 & $(0)$ & 2.63 & $(449)$ & 0.00 & $(0)$ & 2.11 & $(152)$ & \\
\hline T. michelianum cv. Paradana & 1.27 & (44) & 0.00 & (0) & & & & & & & \\
\hline T. ornithopodioides & 0.29 & (6) & 0.00 & $(0)$ & 1.66 & $(50)$ & 0.19 & (2) & 2.91 & $(988)$ & \\
\hline T. purpureum cv. Paratta & 0.16 & (1) & 0.00 & $(0)$ & & & & & 0.00 & $(0)$ & \\
\hline T. resupinatum cv. Nitro Plus & 0.20 & (1) & 0.00 & $(0)$ & 1.95 & (99) & 0.19 & (2) & 0.57 & $(5)$ & \\
\hline T. resupinatum cv. Persian Prolific & 0.94 & (19) & 0.20 & (1) & 2.29 & $(221)$ & & & 0.93 & (16) & \\
\hline T. resupinatum SA33804 & 1.46 & $(101)$ & 0.08 & $(0)$ & & & & & & & \\
\hline & & & & & & & & & & & Formatted: Right: $0.63 \mathrm{~cm}$ \\
\hline
\end{tabular}




\begin{tabular}{lrrrrrrrrrrrrr}
\hline T. spumosum & 0.79 & $(17)$ & 0.00 & $(0)$ & & & & & & & \\
T. squamosum & 0.00 & $(0)$ & 0.00 & $(0)$ & & & 0.19 & $(2)$ & & \\
T. subterraneum cv. Dalkeith & 0.00 & $(0)$ & 0.00 & $(0)$ & & & & & & \\
T. subterraneum cv. Trikkala & 0.61 & $(16)$ & 0.12 & $(1)$ & 1.79 & $(66)$ & 1.35 & $(26)$ & 0.88 & $(32)$ \\
T. tomentosum & 2.98 & $(1127)$ & 0.00 & $(0)$ & 1.54 & $(51)$ & 0.00 & $(0)$ & 1.78 & $(83)$ \\
Trigonella balansae SA5045 & 0.47 & $(8)$ & 0.24 & $(2)$ & 0.47 & $(3)$ & 0.00 & $(0)$ & 0.36 & $(3)$ \\
Site mean & & $(180)$ & & $(12)$ & & $(132)$ & & $(4)$ & & $(120)$ \\
\hline 1.s.d. $(P=0.05)$ & 0.786 & & 0.156 & & 0.511 & & 0.356 & & 0.391 & \\
\hline
\end{tabular}

1 
1 Table 9. Second year spring herbage production ( $\log _{10}$ transformed data) at 5

2 experimental sites $(P<0.001)$. Raw means $(\mathrm{kg} / \mathrm{ha})$ are shown in parentheses.

\begin{tabular}{|c|c|c|c|c|c|c|c|c|c|c|}
\hline \multirow{3}{*}{$\begin{array}{l}\text { Species } \\
\text { Biserrula pelecinus cv. Casbah }\end{array}$} & \multicolumn{10}{|c|}{ Site } \\
\hline & \multicolumn{2}{|c|}{ Tammin } & \multicolumn{2}{|c|}{ Duranillin } & \multicolumn{2}{|c|}{ Cranbrook } & \multicolumn{2}{|c|}{ Girgarre } & \multicolumn{2}{|c|}{ Keith } \\
\hline & 0.29 & (5) & 0.00 & (0) & & & & & & \\
\hline Lotus halophilus & 0.42 & (24) & 0.00 & (0) & & & & & & \\
\hline L. hispidus & 0.00 & $(0)$ & 0.00 & $(0)$ & & & & & & \\
\hline Medicago arabica & 0.49 & (57) & 0.00 & $(0)$ & & & & & & \\
\hline M. polymorpha cv. Cavalier & 3.12 & $(1759)$ & 0.68 & (20) & 3.50 & $(3451)$ & & & & \\
\hline M. polymorpha cv. Santiago & 3.19 & $(1588)$ & 0.00 & $(0)$ & & & & & & \\
\hline M. polymorpha cv. Scimitar & 3.38 & $(2491)$ & 0.34 & (10) & 3.74 & (5549) & 2.50 & $(439)$ & 2.74 & $(604)$ \\
\hline M. scutellata cv. Sava & 2.80 & $(931)$ & 0.00 & $(0)$ & & & & & & \\
\hline M. truncatula cv. Caliph & 3.09 & $(1350)$ & 0.00 & $(0)$ & & & & & & \\
\hline Melilotus albus & & & & & & & & & 0.00 & $(0)$ \\
\hline M. indicus & & & & & & & & & 2.73 & $(646)$ \\
\hline M. infestus & & & & & & & & & 2.79 & $(1047)$ \\
\hline M. italicus & & & & & & & & & 0.00 & $(0)$ \\
\hline M. neopolitanus & & & & & & & & & 0.00 & $(0)$ \\
\hline M. segetalis & & & & & & & & & 0.00 & $(0)$ \\
\hline M. siculus & 0.00 & $(0)$ & 2.77 & $(810)$ & 3.26 & (2119) & & & 2.95 & $(1051)$ \\
\hline M. speciosus & & & & & & & & & 0.00 & $(0)$ \\
\hline M. sulcatus & 0.53 & (9) & 0.00 & $(0)$ & 0.00 & $(0)$ & 0.95 & $(95)$ & 0.00 & $(0)$ \\
\hline Ornithopus pinnatus cv. Jebala & 0.00 & $(0)$ & 0.00 & $(0)$ & & & & & & \\
\hline O. sativus cv. Margurita & 0.00 & $(0)$ & 0.00 & $(0)$ & & & & & & \\
\hline Trifolium alexandrinum & 0.00 & $(0)$ & 0.00 & $(0)$ & & & & & 0.00 & $(0)$ \\
\hline T. clusii & 1.69 & $(494)$ & 0.00 & $(0)$ & & & & & & \\
\hline T. dasyurum cv. AGWEST Sothis & & & & & 0.04 & $(0)$ & & & & \\
\hline T. glanduliferum cv. Prima & 0.00 & $(0)$ & 0.00 & $(0)$ & & & & & & \\
\hline T. incarnatum cv. Caprera & 0.00 & $(0)$ & 0.00 & $(0)$ & & & & & & \\
\hline T. isthmocarpum & 0.64 & (20) & 0.00 & $(0)$ & 3.62 & (4309) & 0.00 & $(0)$ & 0.00 & $(0)$ \\
\hline T. michelianum cv. Bolta & 0.25 & (4) & 0.05 & $(0)$ & 3.39 & $(4034)$ & 0.00 & $(0)$ & 0.00 & $(0)$ \\
\hline T. michelianum $\mathrm{cv}$. Frontier & 1.79 & $(402)$ & 0.34 & (10) & 3.88 & (7683) & 0.00 & $(0)$ & 0.02 & $(0)$ \\
\hline T. michelianum cv. Paradana & 1.60 & $(235)$ & 0.00 & (0) & & & & & & \\
\hline T. ornithopodioides & 0.33 & (9) & 0.00 & $(0)$ & 2.40 & (297) & 0.77 & (33) & 0.00 & $(0)$ \\
\hline T. purpureum cv. Paratta & 0.00 & $(0)$ & 0.00 & $(0)$ & & & & & 0.00 & $(0)$ \\
\hline T. resupinatum cv. Nitro Plus & 0.51 & (9) & 0.34 & (10) & 3.55 & $(3666)$ & 0.38 & (17) & 0.00 & $(0)$ \\
\hline T. resupinatum cv. Persian Prolific & 1.34 & (57) & 0.84 & $(50)$ & 3.84 & $(6414)$ & & & 0.00 & $(0)$ \\
\hline T. resupinatum SA33804 & 1.66 & $(206)$ & 0.00 & $(0)$ & & & & & & \\
\hline T. spumosum & 0.51 & (7) & 0.00 & $(0)$ & & & & & & \\
\hline
\end{tabular}

Formatted: Right: $0.63 \mathrm{~cm}$ 


\begin{tabular}{lrrrrrrrrrrrr}
\hline T. squamosum & 0.00 & $(0)$ & 0.00 & $(0)$ & & & 0.94 & $(87)$ & & \\
T. subterraneum cv. Dalkeith & 0.00 & $(0)$ & 0.00 & $(0)$ & & & & & & \\
T. subterraneum cv. Trikkala & 0.61 & $(13)$ & 0.00 & $(0)$ & 3.40 & $(2750)$ & 2.61 & $(774)$ & 0.00 & $(0)$ \\
T. tomentosum & 2.69 & $(791)$ & 0.00 & $(0)$ & 0.53 & $(38)$ & 2.05 & $(114)$ & 0.00 & $(0)$ \\
Trigonella balansae SA5045 & 0.42 & $(25)$ & 0.34 & $(10)$ & 0.31 & $(7)$ & 1.52 & $(96)$ & 0.00 & $(0)$ \\
Site mean & & $(328)$ & & $(29)$ & & $(2880)$ & & $(150)$ & & $(219)$ \\
\hline l.s.d. $(P=0.05)$ & 0.876 & & 0.473 & & 0.506 & & 0.885 & & 0.226 & \\
\hline
\end{tabular}

1 
1 Table 10. Third year autumn-winter annual legume regeneration densities $\left(\log _{10}\right.$

2 transformed data) at 4 experimental sites $(P<0.001$ at Tammin, Cranbrook and

3 Keith, Duranillin not analysed). Raw means (plants $/ \mathrm{m}^{2}$ ) are shown in parentheses.

\begin{tabular}{|c|c|c|c|c|c|c|c|c|}
\hline \multirow[b]{3}{*}{ Biserrula pelecinus cv. Casbah } & \multicolumn{7}{|c|}{ Site } & \\
\hline & \multicolumn{2}{|c|}{ Tammin } & \multirow{2}{*}{$\begin{array}{c}\text { Duranillin } \\
\text { (0) }\end{array}$} & \multicolumn{2}{|c|}{ Cranbrook } & \multicolumn{2}{|c|}{ Keith } & \\
\hline & 0.36 & (4) & & & & & & \\
\hline Lotus halophilus & 0.69 & (11) & $(0)$ & & & & & \\
\hline L. hispidus & 0.00 & $(0)$ & $(0)$ & & & & & \\
\hline Medicago arabica & 0.29 & $(1)$ & $(0)$ & & & & & \\
\hline M. polymorpha cv. Cavalier & 2.29 & $(267)$ & $(0)$ & 1.97 & (95) & & & \\
\hline M. polymorpha cv. Santiago & 2.72 & $(633)$ & $(0)$ & & & & & \\
\hline M. polymorpha cv. Scimitar & 2.95 & $(903)$ & $(0)$ & 2.00 & $(122)$ & 2.80 & $(651)$ & \\
\hline M. scutellata cv. Sava & 1.76 & $(90)$ & $(0)$ & & & & & \\
\hline M. truncatula cv. Caliph & 2.47 & $(360)$ & $(0)$ & & & & & \\
\hline Melilotus albus & & & & & & 0.00 & $(0)$ & \\
\hline M. indicus & & & & & & 2.38 & (344) & \\
\hline M. infestus & & & & & & 2.82 & (939) & \\
\hline M. italicus & & & & & & 0.00 & $(0)$ & \\
\hline M. neopolitanus & & & & & & 0.00 & $(0)$ & \\
\hline M. segetalis & & & & & & 1.03 & (16) & \\
\hline M. siculus & 0.10 & $(0)$ & $(490) \pm 185^{\mathrm{a}}$ & 2.15 & $(158)$ & 3.00 & $(1018)$ & \\
\hline M. speciosus & & & & & & 0.00 & $(0)$ & \\
\hline M. sulcatus & 0.44 & (3) & $(0)$ & 0.08 & $(0)$ & 0.33 & (9) & \\
\hline Ornithopus pinnatus cv. Jebala & 0.00 & $(0)$ & $(0)$ & & & & & \\
\hline O. sativus cv. Margurita & 0.00 & $(0)$ & $(0)$ & & & & & \\
\hline Trifolium alexandrinum & 0.00 & $(0)$ & $(0)$ & & & 0.00 & $(0)$ & \\
\hline T. clusii & 0.64 & (4) & (0) & & & & & \\
\hline T. dasyurum cv. AGWEST Sothis & & & & 0.00 & $(0)$ & & & \\
\hline T. glanduliferum cv. Prima & 0.00 & (0) & $(0)$ & & & & & \\
\hline T. incarnatum cv. Caprera & 0.00 & $(0)$ & (0) & & & & & \\
\hline T. isthmocarpum & 0.56 & (5) & $(0)$ & 1.94 & $(105)$ & 0.00 & $(0)$ & \\
\hline T. michelianum cv. Bolta & 0.17 & (1) & $(0)$ & 2.01 & $(104)$ & 0.00 & $(0)$ & \\
\hline T. michelianum cv. Frontier & 1.64 & $(78)$ & $(0)$ & 2.22 & $(172)$ & 1.89 & (111) & \\
\hline T. michelianum cv. Paradana & 0.17 & (1) & (0) & & & & & \\
\hline T. ornithopodioides & 0.61 & $(8)$ & $(0)$ & 1.19 & (19) & 2.67 & $(613)$ & \\
\hline
\end{tabular}




\begin{tabular}{lrrrrrrr}
\hline T. purpureum cv. Paratta & 0.00 & $(0)$ & $(0)$ & & & 0.00 & $(0)$ \\
T. resupinatum cv. Nitro Plus & 0.19 & $(1)$ & $(0)$ & 1.73 & $(77)$ & 0.26 & $(4)$ \\
T. resupinatum cv. Persian Prolific & 0.24 & $(3)$ & $(0)$ & 2.10 & $(140)$ & 0.21 & $(2)$ \\
T. resupinatum SA33804 & 1.19 & $(28)$ & $(0)$ & & & & \\
T. spumosum & 0.89 & $(22)$ & $(0)$ & & & & \\
T. squamosum & 0.24 & $(1)$ & $(0)$ & & & & \\
T. subterraneum cv. Dalkeith & 0.73 & $(13)$ & $(0)$ & & & & \\
T. subterraneum cv. Trikkala & 0.10 & $(0)$ & $(0)$ & 1.66 & $(51)$ & 0.55 & $(19)$ \\
T. tomentosum & 2.56 & $(422)$ & $(0)$ & 1.00 & $(10)$ & 2.06 & $(251)$ \\
Trigonella balansae SA5045 & 0.19 & $(2)$ & $(0)$ & 0.18 & $(1)$ & 0.31 & $(2)$ \\
Site mean & & $(89)$ & $(15)$ & & $(75)$ & & $(189)$ \\
\hline 1.s.d. $(P=0.05)$ & 0.532 & & - & 0.303 & 0.466 &
\end{tabular}

1 Standard deviation 
1 Table 11. Third year spring herbage production ( $\log _{10}$ transformed data) at

2 Tammin and Duranillin ( $P<0.001$ at Tammin, Duranillin not analysed). Raw

3 means (kg/ha) are shown in parentheses. Also shown are 0 - 10 ratings for

4 Girgarre $(P<0.01)$. Species with zero production at all sites have been removed

5 from the table.

\begin{tabular}{|c|c|c|c|c|}
\hline \multirow[b]{3}{*}{ Lotus halophilus } & \multicolumn{4}{|c|}{ Site } \\
\hline & \multicolumn{2}{|c|}{ Tammin } & \multirow{2}{*}{$\begin{array}{c}\text { Duranillin } \\
(0)\end{array}$} & \multirow[t]{2}{*}{ Girgarre $(0-10 \text { rating })^{\mathrm{a}}$} \\
\hline & 0.83 & (52) & & \\
\hline Medicago arabica & 0.20 & (2) & (0) & \\
\hline M. polymorpha cv. Cavalier & 3.06 & (2012) & (0) & \\
\hline M. polymorpha cv. Santiago & 3.17 & $(1598)$ & (0) & \\
\hline M. polymorpha cv. Scimitar & 3.37 & $(2369)$ & (0) & 4 \\
\hline M. scutellata cv. Sava & 2.19 & (341) & (0) & \\
\hline M. truncatula cv. Caliph & 3.08 & (1244) & (0) & \\
\hline Melilotus siculus & 0.00 & (0) & $(739) \pm 213^{\mathrm{b}}$ & \\
\hline M. sulcatus & 0.52 & (9) & (0) & 2 \\
\hline T. isthmocarpum & 0.63 & (18) & (0) & 1 \\
\hline T. michelianum cv. Frontier & 2.31 & (434) & (0) & 1 \\
\hline T. michelianum cv. Paradana & 0.65 & (68) & (0) & \\
\hline T. resupinatum SA33804 & 0.21 & (2) & (0) & \\
\hline T. spumosum & 1.29 & (113) & (0) & \\
\hline T. squamosum & 0.23 & (3) & (0) & 0 \\
\hline T. subterraneum cv. Dalkeith & 1.28 & (109) & (0) & \\
\hline T. subterraneum $\mathrm{cv}$. Trikkala & 0.00 & (0) & (0) & 8 \\
\hline T. tomentosum & 2.65 & (474) & (0) & 4 \\
\hline Trigonella balansae SA5045 & 0.23 & (3) & (0) & 0 \\
\hline Site mean & & (277) & (23) & \\
\hline 1.s.d. $(P=0.05)$ & 0.659 & & - & 3.9 \\
\hline
\end{tabular}

$6{ }^{\mathrm{a}} 0=$ no plants of sown species, $10=$ rating of most productive plot

7 Standard deviation

8 


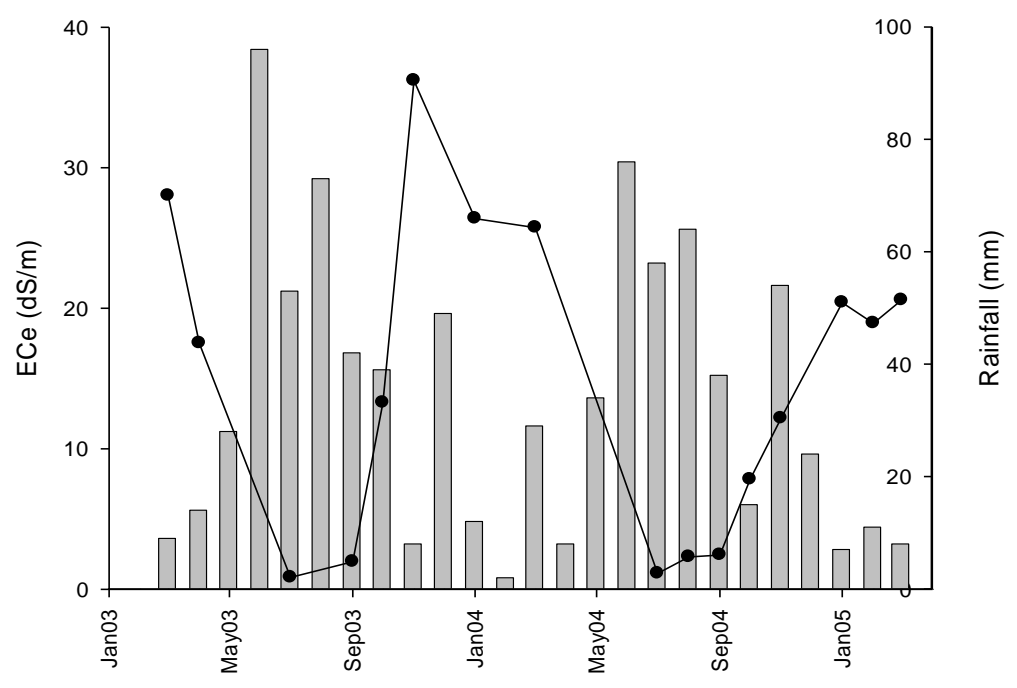

2 Fig. 1. Monthly rainfall (vertical bars) and soil surface $(0-10 \mathrm{~cm})$ salinity levels 3 (solid line) at Keith 
2

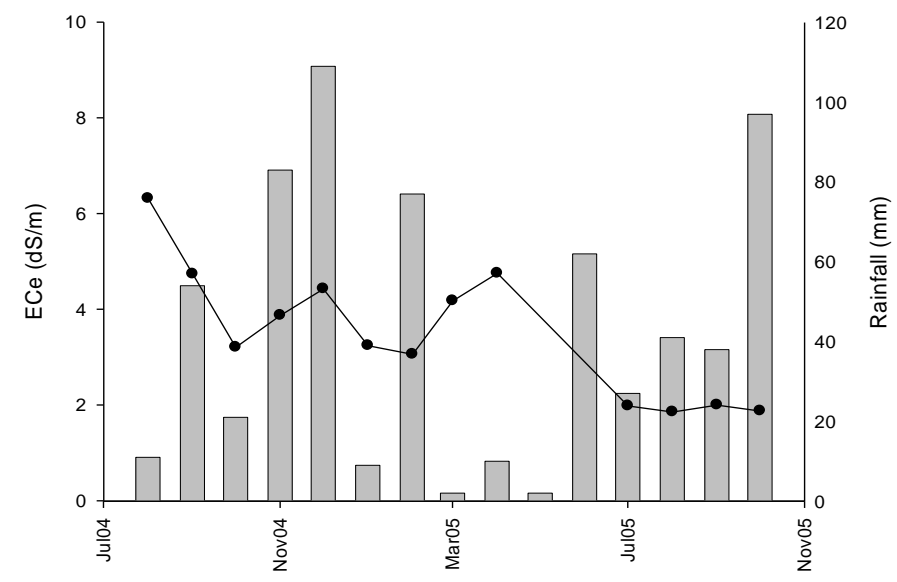

Fig. 2. Monthly rainfall (vertical bars) and soil surface $(0-10 \mathrm{~cm})$ salinity levels (solid line) at Girgarre 